Studia Judaica 20 (2017), nr 2 (40), s. 333-388

doi:10.4467/24500100STJ.17.015.8250

Andrzej Rykała

\title{
Żydowski Instytut Historyczny jako instytut i stowarzyszenie. Profil działalności i zmiany prawno-organizacyjne
}

\author{
THE JEWISH HISTORICAL INSTITUTE AS AN INSTITUTE AND ASSOCIATION: \\ ACTIVITIES AND LEGAL AND ORGANIZATIONAL CHANGES
}

\begin{abstract}
The Central Jewish Historical Commission (CJHC), transformed after three years into the Jewish Historical Institute (JHI), was established in 1944 to collect, inventory, study and edit materials documenting the war experiences of Polish Jews. As a result of its search for the right legal and organizational form, the Jewish Historical Institute Association was initiated in 1950. The establishment of a legal and organizational framework, in conjunction with the tasks the Association had taken on and the means for their implementation, has initiated a close link between the Association and the Institute. These fundamental origins of a strong dependency system conditioned their further development. This paper defines the profile of activities and analyses the legal and organizational changes of the JHI. The time range of the paper covers the period from 1944, the year the CJHC was formed, until the mid-1990s, when the JHI was separated from the JHI Association as a research institute.
\end{abstract}

Keywords: Central Jewish Historical Commission, Jewish Historical Institute Association, Jewish Historical Institute.

Słowa kluczowe: Centralna Żydowska Komisja Historyczna, Stowarzyszenie Żydowski Instytut Historyczny, Żydowski Instytut Historyczny. 


\section{Wstęp. Cel opracowania i baza źródłowa}

W pierwszych latach po II wojnie światowej (do 1950 r.) Żydzi byli jedyną mniejszością narodową w Polsce, która w celu odbudowy podstaw egzystencji, własnej kultury oraz wyrażania szerokiego spektrum koncepcji politycznych stworzyła pewną formę autonomii instytucjonalnej. Zgoda na tę względną niezależność środowiska żydowskiego ze strony władz państwowych - dążących do budowy jednolitego narodowościowo i wolnego od wpływów religii społeczeństwa - miała złożone przyczyny, osadzone zarówno w dynamice zmian geopolitycznych (dokonujących się zwłaszcza na Bliskim Wschodzie), jak i w specyfice przeobrażeń ustrojowych zachodzących w kraju. Od samego początku ramami swoistej autonomii narodowo-kulturalnej objęta została działalność naukowo-badawcza.

Ze względu na moment dziejowy prymarna rola w podejmowaniu szeroko zakrojonych badań nad problematyką żydowską przypadła naukom historycznym. Tragiczne losy Żydów polskich w czasie II wojny światowej wymagały bowiem należycie opracowanych świadectw z tego okresu. Zebranie materiałów źródłowych dokumentujących wojenne losy ludności żydowskiej miało dostarczyć dowodów w procesach sądowych toczonych przeciwko zbrodniarzom wojennym oraz posłużyć do opracowania dziejów okupacji hitlerowskiej ziem polskich. W celu gromadzenia, inwentaryzacji, opracowywania i redagowania materiałów dokumentujących doświadczenia wojenne Żydów polskich powołana została w 1944 r. Centralna Żydowska Komisja Historyczna (CŻKH), przekształcona po trzech latach w Żydowski Instytut Historyczny (ŻIH). W rezultacie poszukiwań odpowiedniej dlań formy prawno-organizacyjnej zainicjowało w $1950 \mathrm{r}$. działalność Stowarzyszenie Żydowski Instytut Historyczny.

Celem tego artykułu jest określenie profilu działalności oraz analiza zmian sytuacji prawno-organizacyjnej Żydowskiego Instytutu Historycznego.

Zakres czasowy artykułu obejmuje okres od daty powstania CŻKH w 1944 r. do połowy lat dziewięćdziesiątych XX w., kiedy ze Stowarzyszenia ŻIH wyodrębnił się ŻIH - Instytut Naukowo-Badawczy.

Do realizacji celu wykorzystałem obszerny materiałźródłowy pozyskany w toku kwerendy w następujących instytucjach: Archiwum Żydowskiego Instytutu Historycznego (AŻIH), Archiwum Akt Nowych (AAN), Instytucie Pamięci Narodowej (IPN), Archiwum Państwowym w Łodzi (APŁ), Archiwum Polskiej Akademii Nauk (APAN), Archiwum Towarzystwa Społeczno-Kulturalnego Żydów w Polsce (ATSKŻ) i Archiwum Stowarzyszenia 
Żydowski Instytut Historyczny (ASŻIH). W dążeniu do przezwyciężenia wątpliwości wynikających z interpretacji i oceny wiarygodności niektórych materiałów archiwalnych posłużyłem się również przetworzonym materiałem źródłowym zawartym w literaturze przedmiotu i pracach monograficznych poświęconych powojennej historii Żydów w Polsce.

\section{U genezy Żydowskiego Instytutu Historycznego - Centralna Żydowska Komisja Historyczna}

Centralna Żydowska Komisja Historyczna ukonstytuowała się 29 sierpnia 1944 r. ${ }^{1}$ w Lublinie jako Komisja Historyczna przy miejscowym Komitecie Żydowskim ${ }^{2}$, będącym instytucjonalnym przedstawicielstwem Żydów ocalałych z Zagłady na terenach opuszczonych przez wycofujące się wojska niemieckie ${ }^{3}$. Na zebraniu założycielskim, 28 grudnia 1944 r., Komisja przyjęła nazwę „Centralna Żydowska Komisja Historyczna”, a jej dyrektorem został historyk, dr Filip Friedman ${ }^{4}$. Pod zmienionym szyldem (jako sekcja) kontynuowała działalność przy Centralnym Komitecie Żydów w Polsce (do lutego 1945 r. - Tymczasowym Centralnym Komitecie Żydów w Polsce - TCKŻP), który ukonstytuował się 29 października 1944 r. na bazie terenowych („wojewódzkich” i „okręgowych”) Komitetów Żydowskich5. Centralny Komitet stał się największą organizacją Żydów polskich, dążącą do reprezentowania ich w charakterze monopolisty w stosunkach z rządem polskim i tzw. zagranicą. Głównym celem tego stowarzyszenia ${ }^{6}$

${ }^{1}$ AŻIH, Akta Organizacyjne [dalej: AO]. Pismo dyrektora ŻIH, Bernarda Marka, do Ministra Handlu Wewnętrznego, z 19 października 1950 r. Zob. także: Noe Grüss, Rok pracy Centralnej Żydowskiej Komisji Historycznej, Łódź 1946, s. 5; Jerzy Tomaszewski, Żydowski Instytut Historyczny w polskiej historiografii, [w:] Żydowski Instytut Historyczny. 50 lat działalności, red. Andrzej Żbikowski, Ewa Biernacka, Warszawa 1996, s. 17; Andrzej Żbikowski, Sąd Spoteczny przy CKŻP. Wojenne rozliczenia społeczności żydowskiej w Polsce, Warszawa 2014, s. 11.

${ }^{2}$ Komitet Żydowski w Lublinie powstał w końcu lipca 1944 r. Maurycy Horn, Działalność naukowa i wydawnicza Centralnej Żydowskiej Komisji Historycznej przy CKŻwP i Żydowskiego Instytutu Historycznego w Polsce w latach 1945-1950, „Biuletyn ŻIH” (1985), nr 1-2, s. 124.

${ }^{3}$ Na początku września 1944 r. spisano pierwsze relacje wojenne Żydów, które pozyskano dzięki specjalnie w tym celu przygotowanej ankiecie.

${ }^{4}$ Grüss, Rok pracy Centralnej Żydowskiej Komisji Historycznej..., s. 7.

${ }_{5}^{5}$ Powołanie Centralnej Komisji Historycznej (CKH) zapowiadał okólnik nr 2 Referatu Historycznego TCKŻP z listopada $1944 \mathrm{r}$.

${ }^{6}$ Stowarzyszenie pod nazwą „Centralny Komitet Żydów w Polsce” z siedzibą w Warszawie zostało wpisane do Rejestru Stowarzyszeń i Związków (nr 95) na mocy postanowienia Prezydenta m.st. Warszawy z 29 maja 1946 r. „Monitor Polski nr 74. Dziennik Urzędowy Rzeczypospolitej Polskiej” z 22 maja 1947 r. 
była pomoc ludności żydowskiej w zaadaptowaniu się do powojennych warunków w Polsce. Zakresem swoich działań, oprócz opieki społecznej i służby zdrowia, aktywizacji gospodarczej, a nawet zaspokajania religijnych potrzeb wyznawców judaizmu, CKŻP objął krzewienie szeroko rozumianej kultury żydowskiej, którego jednym z filarów uczyniono badania naukowe?

W grudniu 1944 r. Komisja Historyczna przystąpiła do zabezpieczania i gromadzenia wszelkich dokumentów i materiałów, które pozwoliłyby odtworzyć najtragiczniejszą kartę w dziejach narodu żydowskiego ${ }^{8}$. Wycofywanie się wojsk niemieckich z kolejnych części ziem polskich odsłaniało przerażające ślady zbrodni na ludności żydowskiej:

W historii niemieckich bestialstw ostatniej wojny stanowi martyrologia żydowska rozdział szczególny, przewyższający swym tragizmem wszystkie inne potworności. [...] Tu bowiem można z całą jaskrawością zaobserwować, do jakich otchłani upodlenia i barbarzyństwa stoczyła się „Trzecia Rzesza”. W walce z Żydami obnażył hitleryzm całą swoją istotę, prawdziwe oblicze nienasyconej krwiożerczej bestii'.

Potrzeba zakrojonego na szeroką skalę udokumentowania Zagłady oraz „poinformowania opinii świata” o niej przyczyniły się do powstania przy Wojewódzkich Komitetach Żydowskich (WKŻ) Wojewódzkich Żydowskich Komisji Historycznych (WŻKH - terenowych oddziałów CŻKH) ${ }^{10}$.

Powoływaniu (Centralnej Żydowskiej) Komisji Historycznej towarzyszyły plany utworzenia również Żydowskiego Naukowego Instytutu

7 Józef Adelson, $W$ Polsce zwanej Ludowa, [w:] Najnowsze dzieje Żydów w Polsce $w$ zarysie (do 1950 roku), red. Jerzy Tomaszewski, Warszawa 1993, s. 426-428; Alina Cała, Helena Datner-Śpiewak, Dzieje Żydów w Polsce 1944-1968. Teksty źródłowe, Warszawa 1997, s. 76-77; Leszek Olejnik, Polityka narodowościowa Polski w latach 1944-1960, Łódź 2003, s. 361-363; Andrzej Rykała, Przemiany sytuacji społeczno-politycznej mniejszości żydowskiej w Polsce po drugiej wojnie światowej, Łódź 2007, s. 130-134; August Grabski, Centralny Komitet Żydów w Polsce (1944-1950). Historia polityczna, Warszawa 2015, s. 9, 15-24.

${ }^{8}$ AŻIH, CŻKH, sygn. 303/XX/37. Memoriał przygotowany przez dyrektora CŻKH, Filipa Friedmana, dla delegacji udającej się do Londynu [bez daty]; IPN GK 162/1114. Pismo dyrektora CŻKH, Filipa Friedmana, do Komisji Głównej dla Badania Zbrodni Niemieckich w Polsce, z 16 września 1945 r.; Pismo dyrektora CŻKH, Filipa Friedmana, do Komisji dla Badania Zbrodni Niemieckich, z 31 października 1945 r.

${ }^{9}$ AŻIH, CŻKH, sygn. 303/XX/38. Cele i zadania CŻKH w Polsce opracowane przez jej dyrektora, Filipa Friedmana [bez daty].

${ }^{10}$ Celem WŻKH - powołanych na mocy wspomnianego okólnika nr 2 - było zebranie „materiałów napływających od poszczególnych korespondentów”. Pierwotnie działania tych agend koncentrowały się na gromadzeniu świadectw zbrodni na terenach opuszczonych już przez Niemców (m.in. w obozach zagłady w Sobiborze, Majdanku i Treblince). Wraz z upływem czasu, znaczonym wyzwalaniem kolejnych ziem spod okupacji niemieckiej, w zakres badań komisji weszły inne zagadnienia (dotyczące gett, martyrologii dzieci, ruchu oporu, ocalałych po tzw. aryjskiej stronie). 
Historycznego, z siedzibą w „stolicy Państwa polskiego”. Podstawowym zadaniem tej placówki miało być „prowadzenie badań naukowych nad historią Żydów w Polsce oraz krzewienie i popularyzacja żydowskiej wiedzy historycznej”, „głównym celem aktualnych prac” natomiast - „zbadanie całokształtu procesu zagłady żydostwa w okresie okupacji niemieckiej, opracowanie i opublikowanie tego materiału" ${ }^{11}$. Zakładano, że Instytut będzie zależny od Centralnej Komisji Historycznej, w której gestii miało pozostać mianowanie jego dyrektora. Profil działalności Instytutu miały kształtować CKŻP oraz, powstały w listopadzie 1944 r., Związek Literatów, Dziennikarzy i Artystów Żydowskich w Polsce (ZLDiAŻ) - drugi, prócz Komitetu, „gorący poplecznik i promotor” CŻKH ${ }^{12}$. Przy Instytucie planowano bowiem powołać Kuratorium - „równoznaczne z Centralną Komisją Historyczną” - składające się z osób delegowanych przez Komitet i Związek. W zakres kompetencji tego organu wpisano wyrażanie opinii „w sprawach wyniku prac dokonanych oraz planów dalszego rozwoju Instytutu", zatwierdzanie budżetu, a także uchwalanie statutu i regulaminu ${ }^{13}$. Plany co do powołania Instytutu rodziły się jednocześnie z pracami nad formowaniem CKŻP, ponieważ za podstawę jego finansowania przyjmowano dotacje $\mathrm{z}$ funduszów państwowych i społecznych, subwencje oraz legaty, nie zaś konkretnie środki pochodzące z Komitetu. Placówka stanowić miała „podstawę dla utworzenia w przyszłości Żydowskiego Towarzystwa Naukowego zrzeszającego w swych ramach badaczy żydowskich z rozmaitych dziedzin wiedzy"14.

Choć Historyczny Instytut Naukowy, jak wynika z materiałów źródłowych, zainicjował działalność, to jednak nie przybrał formy odrębnej agendy ${ }^{15}$. Nie nadano mu również, nakreślonej w planach, struktury wewnętrznej. Można przyjąć, że jego niesformalizowaną działalność

11 AŻIH, CŻKH, sygn. 303/XX/5. Statut Żydowskiego Naukowego Instytutu Historycznego.

12 AŻIH, CŻKH, sygn. 303/XX/38. Cele i zadania CŻKH w Polsce opracowane przez jej dyrektora, Filipa Friedmana [bez daty]; Grüss, Rok pracy Centralnej Żydowskiej Komisji Historycznej..., s. 6-7. Blisko z CŻKH współpracowało również, utworzone w październiku 1946 r., Żydowskie Towarzystwo Krzewienia Sztuk Pięknych (ŻTKSP). Maurycy Horn, Działalność Żydowskiego Instytutu Historycznego w Polsce w latach 1944-1979, [w:] 35 lat działalności Żydowskiego Instytutu Historycznego w Polsce Ludowej, Warszawa 1980, s. 11.

13 Zob. przyp. 11.

14 Tamże.

15 AŻIH, CŻKH, sygn. 303/XX/38. Cele i zadania CŻKH opracowane przez jej dyrektora, Filipa Friedmana [bez daty]. W sprawozdaniu z działalności Komisji Friedman stwierdził, że „Oprócz Centralnej Żydowskiej Komisji Historycznej stworzyliśmy Historyczny Instytut Naukowy" - zob. tamże, sygn. 303/XX/37. Memoriał przygotowany przez dyrektora CŻKH, Filipa Friedmana, dla delegacji udającej się do Londynu [bez daty]. 
wyznaczał zakres realizowanych zadań: systematyzowanie i naukowe opracowywanie materiału zebranego przez Ċ̇KH, a także sprawowanie „fachowego kierownictwa” nad tymi zbiorami. „Dookoła [...] Instytutu jak stwierdzał Filip Friedman - zgromadziły się najpoważniejsze żydowskie siły naukowe pozostałe przy życiu"16. Instytut należałoby więc utożsamiać z tym zespołem pracowników CŻKH, którzy skoncentrowali swoją aktywność na pracy naukowo-badawczej ${ }^{17}$.

Po przeniesieniu, w lutym 1945 r., siedziby do Łodzi - największego z najmniej zniszczonych miast polskich, będącego tuż po wojnie centrum życia społeczności żydowskiej - CŻKH weszła w bardziej dynamiczny, a zarazem stabilny etap rozwoju ${ }^{18}$. Nieformalną stolicę Polski od początku traktowano jednak jako siedzibę tymczasową, dając temu wyraz w statucie CŻKH, gdzie zapisano, że „Siedzibą Komisji będzie stolica państwa Polskiego - Warszawa" ${ }^{\text {. }}$.

Działalność w terenie Komisja prowadziła poprzez sieć wojewódzkich (w Białymstoku, Gdańsku, Katowicach, Krakowie, Lublinie, Łodzi, Warszawie i we Wrocławiu) oraz lokalnych (oprócz wymienionych miast również w Bielsku, Częstochowie, Kielcach, Kutnie, Piotrkowie Trybunalskim, Przemyślu, Radomiu, Tarnowie, we Włocławku i innych) Komisji Historycznych. W przypadku braku możliwości ich powołania zbieraniem informacji (głównie w mniejszych miastach) zajmowali się korespondenci $\mathrm{CZZKH}^{20}$, którzy wyniki swoich prac przesyłali do regionalnych oddziałów ${ }^{21}$.

${ }^{16}$ AŻIH, CŻKH, sygn. 303/XX/37. Memoriał przygotowany przez dyrektora CŻKH, Filipa Friedmana, dla delegacji udającej się do Londynu [bez daty].

${ }^{17} \mathrm{Z}$ przeprowadzonych czynności rewizyjno-lustracyjnych wynikało, że spośród 33 pracowników CZZKH (ustalonych na podstawie listy płac) 14 należało do „Instytutu naukowego". AŻIH, CŻKH, sygn. 303/XX/95. Sprawozdanie z rewizji i lustracji ksiąg w CKH w lipcu $1945 \mathrm{r}$.

${ }^{18}$ Noe Grüss sytuację w Lublinie i jej wpływ na działalność CŻKH opisał w następujący sposób: „W pierwszym okresie swojego istnienia Komisja zebrała mało materiałów. Kipiący życiem Lublin, ówczesna stolica Polski, nie sprzyjał pracy badawczej. Zawrotna szybkość następujących po sobie wydarzeń historycznych i trwające jeszcze działania wojenne absorbowały ludzi, działały hamująco na pracę, która wymaga z jednej strony spokoju, z drugiej specjalistów-fachowców". Grüss, Rok pracy Centralnej Żydowskiej Komisji Historycznej..., s. 6.

${ }_{19}$ AŻIH, CŻKH, sygn. 303/XX/3. Statut CŻKH przy CKŻP. Niemal rok po przeniesieniu do Łodzi (6 lutego 1946 r.) CŻKH wystąpiła z oficjalną prośbą o zarejestrowanie do Starostwa Grodzkiego-Śródmiejskiego - zob. tamże, sygn. 303/XX/162.

${ }^{20}$ Zob. przyp. 9.

${ }^{21}$ W przywołanym już okólniku nr 2 przyjęto, aby w każdym mieście będącym siedzibą Komitetu Żydowskiego powołać korespondenta, który miałby spisać okupacyjne losy każdego Żyda, jego rodziny i najbliższych. Zob. AŻIH, CŻKH, sygn. 303/XX/38. Cele i zadania CŻKH opracowane przez jej dyrektora, Filipa Friedmana [bez daty]. Należy podkreślić, że nomenklatura, którą stosowano wobec korespondentów (opłacanych za nadesłany materiał), nie była ujednolicona (posługiwano się na ich określenie zarówno danymi personalny- 
W Łodzi urządzono Centralne Archiwum Komisji, w którym gromadzono wszelkie materiały pochodzące z Wojewódzkich Komisji Historycznych. W archiwach oddziałów terenowych zatrzymywano jedynie odpisy ${ }^{22}$. W skład głównego archiwum weszły okupacyjne akta różnych urzędów, instytucji, organizacji oraz osób prywatnych, w tym należące do największych i najcenniejszych: akta niemieckiej (Ghettoverwaltung) i żydowskiej (tzw. Archiwum Rumkowskiego) administracji getta łódzkiego ${ }^{23}$. W 1946 r. archiwalia wzbogaciły się o część zbiorów konspiracyjnego archiwum getta warszawskiego (tzw. Archiwum Ringelbluma). Po przenosinach do Łodzi „skromne zbiory Komisji w Lublinie zostały niepomiernie powiększone”24.

W okresie łódzkim, poza archiwum, CŻKH utworzyła muzeum i bibliotekę oraz zaczęła deponować inne zbiory (ikonograficzne, artystyczne). Realizując jeden z podstawowych celów, jakim było opracowanie świadectw Żydów polskich z okresu Zagłady, Komisja powiększyła zbiory archiwaliów o źródła wywołane (relacje ocalałych), do których dołączyły dzienniki, pamiętniki i inne dokumenty. Będące w posiadaniu CŻKH zasoby wzbogaciły się również o poezję i inne formy literackie, fotografie, dzieła malarstwa, rzeźby i utwory muzyczne. W celu pełnego zobrazowania bezprzykładnej zbrodni na Żydach wykonywano liczne odpisy i fotokopie dokumentów pozyskanych od innych instytucji i osób prywatnych ${ }^{25}$.

Na czele CŻKH stała Egzekutywa (wyłaniająca spośród swoich członków przewodniczącego Komisji), natomiast całokształtem pracy naukowej kierowała Rada Naukowa. O podporządkowaniu Komisji CKŻP świadczył sposób jej finansowania. Fundusze CŻKH pochodziły ze stałej dotacji

mi, jak i konkretnymi nazwami: „oddział”, „komisja historyczna”, „,wojewódzka żydowska komisja historyczna"), co świadczyło o tymczasowości i nieprecyzyjnie określonym statusie funkcjonowania tych agend w strukturze organizacyjnej CZZKH.

${ }^{22}$ W maju 1946 r. oddziały Komisji (lub korespondenci) mieściły się w Krakowie, Warszawie, Białymstoku, Lublinie, Przemyślu, we Wrocławiu, w Katowicach, Rychbachu (obecnie Dzierżoniów), Bytomiu, Piotrolesiu (obecnie Pieszyce). AŻIH, CŻKH, sygn. 303/ XX/10. Protokół posiedzenia Egzekutywy CŻKH z 1 maja 1946 r.; IPN GK 162/1114. Odpis pisma WŻKH w Katowicach do CŻKH w Polsce, z 22 października 1946 r.

${ }^{23}$ APŁ, Zarząd Miasta Łodzi [dalej: ZMŁ], Wydział Administracyjny [dalej: WA], sygn. 148. Raport z lustracji w CŻKH i Towarzystwie Przyjaciół ŻKH przy CKŻP, przeprowadzonej w 1946 r. przez urzędników Starosty Grodzkiego Śródmiejsko-Łódzkiego i Archiwum Miejskiego.

${ }^{24}$ AŻIH, CŻKH, sygn. 303/XX/26. Sprawozdanie z działalności CŻKH (1944-1947).

${ }_{25}$ AŻIH, CŻKH, sygn. 303/XX/38. Cele i zadania CŻKH opracowane przez jej dyrektora, Filipa Friedmana [bez daty]. IPN GK 162/1114. Pismo dyrektora CŻKH, Filipa Friedmana, do Komisji Głównej dla Badania Zbrodni Niemieckich w Polsce, z 16 września 1945 r.; Pismo dyrektora CŻKH, Filipa Friedmana, do Komisji dla Badania Zbrodni Niemieckich, z 31 października $1945 \mathrm{r}$. 
Komitetu, dorywczych subwencji i dochodów z wydawnictw. Komitet zatwierdzał też ułożony przez Egzekutywę budżet Komisji ${ }^{26}$.

W kwietniu 1947 r. CŻKH rozpoczęła intensywne starania o zmianę siedziby, tym razem na Warszawę. Przenosinom do stolicy, w której odradzało się centrum życia społeczności żydowskiej, towarzyszyły przekształcenia o charakterze organizacyjno-prawnym. Komisja podjęła się bowiem wypełnienia jednego z warunków zapisanych w swoim statucie. Stając się instytucją skupiająca , wokół siebie specjalistów w zakresie wymienionych badań i pokrewnych”, stworzyła „podstawę dla utworzenia [...] Żydowskiego Instytutu Historycznego" (par. 6) ${ }^{27}$. Realizacji idei zmierzającej do powołania instytutu sprzyjała baza materialna. Komisja na swoją nową siedzibę pozyskała gmach przy ul. Tłomackie 5, w którym przed wojną (od 1936 r.) mieścił się Instytut Nauk Judaistycznych. Odwołując się do tradycji przedwojennego Instytutu, a jednocześnie wypełniając cele statutowe Komisji, Prezydium Komitetu na posiedzeniu 3 maja 1947 r. podjęło uchwałę o przekształceniu CŻKH w Żydowski Instytut Historyczny przy CKŻP z siedzibą w Warszawie ${ }^{28}$. Na tym samym posiedzeniu dyskutowano również nad nienowym postulatem powołania instytucji o szerszym profilu merytorycznym, jakim miał być Żydowski Instytut Naukowy ${ }^{29}$. Warto tu pokreślić, że zmianę nazwy (z CŻKH na ŻIH) uchwalono już 27 stycznia 1947 r. na posiedzeniu Prezydium CKŻ ${ }^{30}$.

Z prośbą o legalizację instytucji pod nazwą „Żydowski Instytut Historyczny" CKŻP wystąpił 20 maja tegoż roku do Zarządu Miejskiego w Warszawie $^{31}$. Z dniem 3 września CŻKH, która weszła w stan likwidacji, prze-

${ }^{26}$ AŻIH, CŻKH, sygn. 303/XX/3. Statut CŻKH przy CKŻP.

${ }^{27} \mathrm{~W}$ innej wersji statutu CŻKH przy CKŻP zamiast zwrotu „Żydowski Instytut Historyczny” figuruje nazwa „Żydowski Instytut Naukowy”. Tamże.

${ }^{28} \mathrm{O}$ działalności Instytutu informował p. 10 art. 3 Statutu CKŻP. AŻIH, CKŻP, Prezydium i Sekretariat [dalej: PiS], sygn. 303/I/73. Pismo CKŻP do Oddziału Społeczno-Politycznego Wydziału Administracyjnego ZMŁ z 20 grudnia 1947 r., wyjaśniające (w odpowiedzi na pismo „tamtejsze” z 28 lutego 1947 r.) podstawy prawne przekształcenia CŻKH w ŻIH.

${ }^{29}$ Nachman Blumental, członek CŻKH, postulował, aby „w jednej instytucji skupione były wszystkie inne, mające pokrewne cele dla scentralizowania działalności. Instytut [...] nie może być instytutem teoretycznym, lecz badać sprawy i realizować postulaty w dziedzinie wychowania (poradnie psychologiczne), szkolnictwa (podręczniki). [...] Mieliśmy zamiar stworzyć [...] Ż.I. Naukowy, ale nie mamy dosyć ludzi, a poza tym z punktu widzenia skromności - zdecydowaliśmy się na Ż.I.H., który w przyszłości będzie przekształcony na Żydowski Instytut Naukowy”. AŻIH, CKŻP, PiS, sygn. 303/I/21. Protokół z posiedzenia Prezydium CKŻP, z 3 maja 1947 r.

${ }^{30}$ Tamże, sygn. 303/I/20. Protokół z posiedzenia Prezydium CKŻP z 27 stycznia 1947 r.

31 Tamże, sygn. 303/I/70. Pismo przewodniczącego i generalnego sekretarza CKŻP do Wydziału Społeczno-Politycznego Zarządu Miejskiego w Warszawie, z 20 maja 1947 r. 
niosła siedzibę z Łodzi do stolicy Polski ${ }^{32}$. Przeprowadzka całej instytucji trwała około dwóch miesięcy (wrzesień-październik) ${ }^{33}$. Formalnie, na mocy uchwały Prezydium CKŻP z 27 września 1947 r., ŻIH rozpoczął działalność 1 października tego roku $^{34}$. Do czasu wyznaczenia Zarządu i Rady Naukowej - organów mających stać na czele Instytutu - pracom nowej jednostki przewodziło trzyosobowe „prowizorium” ${ }^{35}$. Reorganizacja, polegająca na przekształceniu Komisji w Instytut, przebiegła stosunkowo sprawnie, gdyż już 3 października 1947 r. pod adresem ŻIH wpłynęło pismo Sędziego Okręgowego Śledczego w Krakowie w sprawie sporządzenia odpisu rejestrów 30 tys. Żydów wysiedlonych z Krakowa ${ }^{36}$. W związku z transformacją z dniem 1 października $1947 \mathrm{r}$. wypowiedziano umowy byłym pracownikom CŻKH zatrudnionym w oddziałach terenowych (w Katowicach, Krakowie, Łodzi, Szczecinie i Wałbrzychu) ${ }^{37}$. Struktury te nie uległy jednak likwidacji. Instytut zreorganizował je w oddziały - z siedzibami w Lodzi i Krakowie - oraz delegatury: w Białymstoku, Katowicach, Szczecinie, Wałbrzychu i we Wrocławiu. Oddziały i delegatury, wzorem działających w terenie jednostek CŻKH, miały za zadanie zbieranie zeznań oraz materiałów dowodowych tyczących się przestępców wojennych, materiałów dokumentalnych, fotografiki, muzealiów ${ }^{38}$. Z końcem 1948 r. wszystkie delegatury przestały istnieć $\mathrm{z}$ „powodu wyczerpania się materiałów”39.

Do Zarządu Instytutu, powołanego 16 października 1947 r. przez CKŻP, weszli dawni działacze CŻKH. Zgodnie bowiem z postanowieniami projektu

${ }^{32}$ AŻIH, CŻKH, sygn. 303/XX/109. Pismo dyrektora i sekretarza generalnego CŻKH do CKŻP, z 28 sierpnia 1947 r.; IPN GK 162/1114. Informacja ŻIH dla Głównej Komisji Badania Zbrodni Niemieckich w Polsce (październik 1947 r.).

${ }_{33}$ AŻIIH, AO. Pismo dyrektora ŻIH, Nachmana Blumentala, do Głównej Komisji Badania Zbrodni Niemieckich w Polsce, z 6 listopada 1947 r., w sprawie rozliczenia zaliczki.

${ }^{34}$ ASŻIH. Protokół z posiedzenia Prezydium CKŻP, z 27 września 1947 r.

${ }_{35}$ AŻIH, CKŻP, PiS, sygn. 303/I/22. Protokół z posiedzenia Prezydium CKŻP, z 27 września $1947 \mathrm{r}$.

${ }^{36}$ AŻIH, AO. Pismo Sędziego Okręgowego Śledczego w Krakowie do ŻIH przy CKŻP w Warszawie, z 3 października 1947 r., w sprawie sporządzenia odpisu rejestrów 30 tys. Żydów wysiedlonych z Krakowa przez B. [byłego] Stadthauptmanna miasta Krakowa Rudolfa Pavlu.

${ }^{37}$ AŻIH, AO; CKŻP, PiS, sygn. 303/I/73. Pismo dyrektora ŻIH, Nachmana Blumentala, do Prezydium CKŻP, z 25 października 1947 r., w sprawie wypowiedzenia pracy osobom zatrudnionych w oddziałach CŻKH.

${ }^{38}$ W celu realizacji swoich zadań oddziały i delegatury miały nawiązać ścisłą współpracę z miejscowymi Komitetami Żydowskimi (m.in. działającymi przy nich Wydziałami Młodzieżowymi), ziomkostwami, żydowskimi nauczycielami, Związkiem Partyzantów Żydowskich. ASŻIH. Okólnik Nr 1 ŻIH z 27 listopada 1947 r.

${ }^{39}$ Przyczyn likwidacji większości jednostek upatrywano również w niewłaściwie prowadzonej pracy terenowych działaczy. AŻIH, CKŻP, PiS, sygn. 303/I/31. Protokół z posiedzenia Prezydium CKŻP, z 5 stycznia 1949 r. 
statutu organ ten tworzyć miało pięciu członków mianowanych przez CKŻ $\mathrm{P}^{40}$. Zarząd ukonstytuował się na swym pierwszym posiedzeniu 23 października tegoż roku. Wtedy też zaopiniowano wniosek o utworzenie Rady Naukowej Instytutu, której skład przedłożono do zatwierdzenia CKŻ ${ }^{41}$. Uchwałę o powołaniu organu doradczego ŻIH w sprawach naukowo-badawczych Prezydium Komitetu podjęło jednak dopiero 29 lipca 1949 r. ${ }^{42}$ Dyrektorem Instytutu został Nachman Blumental ${ }^{43}$. W tymże dniu zastąpił go na tym stanowisku inny działacz dawnej CŻKH, Bernard (Ber) Mark ${ }^{44}$.

Żydowski Instytut Historyczny podjął się realizacji ,jednego ze swych najgłówniejszych zadań: stworzenia Centralnego Archiwum Żydostwa Polskiego" ${ }^{45}$. W związku z tym zaapelował o niezwłoczne przeniesienie do archiwum Instytutu w Warszawie wszystkich żydowskich zbiorów archiwalnych ${ }^{46}$. W pierwszej kolejności przejął zbiory będące w posiadaniu dawnych Wojewódzkich Żydowskich Komisji Historycznych ${ }^{47}$. Instytut dążył jednak do skoncentrowania i uporządkowania w archiwum Ż̇H resztek wszystkich archiwaliów żydowskich ocalałych po okupacji hitlerowskiej (m.in. ksiąg ludności cywilnej, czasopism żydowskich) - znajdujących się pod opieką Dyrekcji Archiwów Państwowych Ministerstwa Oświaty oraz bibliotek - w celu udostępnienia ich w jak najszybszym czasie badaczom $^{48}$. W dalszej kolejności Instytut przejął (16 marca 1949 r.) działającą przy CKŻP Centralną Bibliotekę Żydowską (CBŻ) ${ }^{49}$, która przez pięć lat

40 Tamże, sygn. 303/I/21. Protokół z posiedzenia Prezydium CKŻP, z 3 maja 1947 r.

${ }^{41}$ AŻIH, AO. Pismo dyrektora ŻIH, Nachmana Blumentala, do CKŻP, z 24 października 1947 r., w sprawie ukonstytuowania się Zarządu ŻIH oraz listy kandydatów do Rady Naukowej Instytutu.

42 AŻIH, CKŻP, PiS, sygn. 303/I/33. Protokół z posiedzenia Prezydium CKŻP z 29 lipca $1949 \mathrm{r}$.

${ }^{43}$ ASŻIH, Okólnik Nr 1 ŻIH z 27 listopada 1947 r.

${ }^{44}$ AŻIH, CKŻP, PiS, sygn. 303/I/33. Protokół z posiedzenia Prezydium CKŻP z 29 lipca 1949 r.; zob. także Maurycy Horn, Szkic z przeszłości Żydowskiego Instytutu Historycznego w Polsce (1949-1966), „Biuletyn ŻIH” (1979), nr 2, s. 3.

${ }^{45}$ AŻIH, AO. Pismo dyrektora ŻIH, Nachmana Blumentala, do Prezydium CKŻP, z 23 października 1947 r., dotyczące przystąpienia do realizacji planu utworzenia Centralnego Archiwum Żydostwa Polskiego.

${ }^{46}$ Tamże. Zob. także: AŻIH, AO. Pismo dyrektora ŻIH, Bernarda Marka, do Miejskiej Rady Narodowej w Krakowie, z 25 października 1949 r., w sprawie akt byłej Gminy Żydowskiej na Kazimierzu z lat 1816-1870.

${ }_{47}$ Zob. przyp. 45.

48 AŻIH, AO. Pismo dyrektora ŻIH, Nachmana Blumentala, do Prezydium CKŻP, z 21 listopada 1947 r., w sprawie przekazania w depozyt (do czasu ustalenia zasad prawnych przejęcia) własności byłej Gminy Wyznaniowej Żydowskiej w Krakowie.

${ }^{49} \mathrm{~W}$ oficjalnym obiegu pism biblioteka (z siedzibą w Warszawie) występowała pod nazwą „Centralnej Biblioteki Żydowskiej przy CKŻP”. AAN, Ministerstwo Oświaty [dalej: 
skupiła w swych magazynach pokaźne zbiory druków ${ }^{50}$ (głównie w jidysz i języku hebrajskim) $)^{51}$. W wyniku połączenia zasobów CBŻ ze znacznie mniejszym księgozbiorem biblioteki rozwiązanej CŻKH powstała Biblioteka ŻIH (jako ,jednostka zamknięta” nie nosiła charakteru wypożyczalni publicznej, lecz stanowiła zespół pomocniczo-naukowy służący celom wyłącznie badawczo-naukowym $)^{52}$. Instytut przystąpił również do reorganizacji muzeum, podejmując starania o przyjęcie go do Związku Muzeów ${ }^{53}$. Zamiast muzeum otworzył jednak, 19 kwietnia 1948 r., Salę Muzealną ${ }^{54}$, która została wpisana na listę placówek objętych opieką (subwencją) Naczelnej Dyrekcji Muzeów i Ochrony Zabytków Ministerstwa Kultury i Sztuki ${ }^{5}$. Choć w korespondencji z ŻIH Naczelna Dyrekcja określała ją mianem „Muzeum Historycznego Instytutu Żydowskiego przy C.K. Żydów w Polsce”, dział muzealny nie stanowił oddzielnej jednostki administracyjno-finansowej, ale część składową ŻIH.

Poza kontynuacją pracy dokumentacyjnej, działalności naukowej oraz współpracy z instytucjami i organizacjami zajmującymi się badaniem zbrodni hitlerowskich i ściganiem zbrodniarzy wojennych Instytut powziął nowe działania polegające $m$.in. na poszukiwaniu dalszych części

MO], sygn. 6837. Pismo kierowniczki CBŻ przy CKŻP, Barbary Bermanowej, do Wydziału Bibliotek Ministerstwa Oświaty, z 18 października 1945 r. Zob. też tamże, sygn. 6848. Pismo Barbary Bermanowej do Naczelnej Dyrekcji Bibliotek Polskich Ministerstwa Oświaty, z 4 marca 1947 r., w sprawie subwencji.

${ }^{50}$ Do najcenniejszych zbiorów, liczącej ok. 50 tys. woluminów biblioteki, należały rzadkiej wartości książki (m.in. druki z XVI-XVIII w.) i rękopisy (XIII-XVIII w.) zrabowane przez hitlerowców w Warszawie, we Wrocławiu, w Berlinie, Pradze, Wiedniu i innych miastach, a następnie znalezione w podziemiach gestapo w Kłodzku.

${ }^{51}$ AŻIH, CKŻP, PiS, sygn. 303/I/79. Pismo dyrektora ŻIH, Nachmana Blumentala, do CKŻP, z 12 kwietnia 1949 r., w sprawie ustalenia budżetu, liczby i rodzajów etatów zaplanowanych przez Prezydium Komitetu dla CBŻ po przeprowadzeniu jej reorganizacji.

${ }_{52}$ AŻIH, AO. Pismo dyrektora ŻIH, Bernarda Marka, do Kuratorium Okręgu Szkolnego (Wydziału Kontroli Bibliotek), z 27 sierpnia 1949 r., w sprawie przesłania książek.

${ }_{53}$ AŻIH, AO. Pismo dyrektora ŻIH, Nachmana Blumentala, do Związku Muzeów, z 3 października 1947 r., w sprawie przesłania publikacji „Muzealnictwo” i udzielenia informacji o warunkach przyjęcia do Związku Muzeów.

${ }_{54}$ Sala została otwarta 19 kwietnia 1948 r. przez przedstawiciela rządu polskiego. Inauguracyjną wystawę poświęcono martyrologii i walce Żydów polskich w czasie okupacji hitlerowskiej.

${ }_{55}$ AŻIH, AO. Pismo Naczelnego Dyrektora Muzeów i Ochrony Zabytków do ŻIH, z 3 czerwca 1949 r., o obowiązku nadesłania przez dyrekcję muzeum planu oszczędnościowego na 1949 r.; Odpowiedź dyrektora ŻIH, skierowana do Dyrektora Departamentu Administracyjnego i Komisarza Oszczędnościowego Ministerstwa Kultury i Sztuki, z 20 maja 1949 r., w sprawie prowadzenia Sali Muzealnej; Pismo dyrektora ŻIH, Bernarda Marka, do American Joint Distribution Committee, z 5 listopada 1949 r., w sprawie przekazania muzealiów do organizującego się Centralnego Muzeum Żydów Polskich przy ŻIH. 
archiwum Emanuela Ringelbluma oraz wydawaniu, od stycznia 1948 r., kwartalnika historycznego w jidysz „Bleter far Geszichte” ${ }^{56}$.

Żydowski Instytut Historyczny, jako instytucja badawczo-naukowa, nie tylko nie był jednostką samodzielną (funkcjonował jako Żydowski Instytut Historyczny przy C.K. Żydów w Polsce), ale i nie posiadał zalegalizowanego statutu ${ }^{57}$. W związku z tym do występowania o subwencje lub inną pomoc pieniężną ze Skarbu Państwa na wykonanie zadań statutowych upoważniony był przede wszystkim CKŻ $\mathrm{P}^{58}$. We własnym imieniu o wyasygnowanie określonych kwot ŻIH zwracał się głównie do innych organizacji żydowskich w Polsce i poza jej granicami (m.in. do American Joint Distribution Committee [dalej: Joint] ${ }^{59}$.

Instytut utrzymywał się więc z subwencji państwowych i środków społecznych. W latach 1948-1950 subwencje na działalność ŻIH pochodziły z CKŻP i dwóch ministerstw: Ministerstwa Oświaty oraz Ministerstwa Kultury i Sztuki (MKiS) ${ }^{60}$. W 1949 r. Instytut wystąpił z prośbą do Komisji Popierania Twórczości Naukowej i Artystycznej przy Prezydium Rady Ministrów (PRM), a później również do Departamentu Nauki Ministerstwa Oświaty o przejęcie go z dniem 1 stycznia 1950 r. „na budżet państwowy”61.

${ }^{56}$ AŻIH, CŻKH, sygn. 303/XX/109. Pismo dyrektora CŻKH do CKŻP z 23 maja 1947 r. Zob. także: AŻIH, AO. Pismo dyrektora ŻIH, Nachmana Blumentala, do dyrekcji AJDC, z 21 października 1947 r., w sprawie planów pracy Instytutu oraz środków potrzebnych na ich realizację; Pismo dyrektora ŻIH, Nachmana Blumentala, do Prezydium CKŻP, z 10 listopada 1947 r., z apelem o dalsze poszukiwania drugiej części archiwum Ringelbluma.

${ }^{57}$ Instytut traktowano także jako składową struktury wewnętrznej Komitetu. W piśmie do Zarządu Głównego Zakładu Osiedli Robotniczych Nachman Blumental komunikował, że ŻIH ,jako część składowa C.K. Żydów w Polsce, nie posiada środków własnych na budowę mieszkań dla swych pracowników”. AŻIH, AO. Odpowiedź dyrektora ŻIH na pismo ZG Zakładu Osiedli Robotniczych, z 24 sierpnia 1949 r., dotyczące planu inwestycyjnego budownictwa mieszkaniowego na $1950 \mathrm{r}$. W innym piśmie zakomunikowano wprost, że ŻIH jest ,jedną z placówek Centralnego Komitetu Żydów w Polsce [...], i nie posiada przeto własnego statutu" - zob. AŻIH, AO. Pismo Kierownika Biura ŻIH, Adama Rutkowskiego, do 13. Oddziału Wydziału Finansowego Prezydium Rady Narodowej, z 7 sierpnia 1950 r., dotyczace statusu Instytutu.

${ }_{58}$ AŻIH, CKŻP, PiS, sygn. 303/I/78. Odpowiedź, z 22 lutego 1947 r., skierowana przez wicedyrektora Biura Komitetu Ministrów do spraw Kultury do ŻIH przy CKŻP w sprawie wniosku o subwencję dla Instytutu.

${ }^{59}$ AŻIH, AO. Pismo dyrektora ŻIH, Nachmana Blumentala, do dyrekcji Joint, z 21 października 1947 r., w sprawie planów pracy Instytutu oraz środków potrzebnych na ich realizację.

${ }^{60}$ AŻIH, AO. Zaświadczenie o działalności ŻIH dla starostwa m.st. Warszawy, wystosowane 19 grudnia 1949 r. przez kierownika biura Instytutu, Abrama Rosenberga.

${ }^{61}$ AŻIH, AO; AAN, MO, sygn. 3221. Pismo dyrektora ŻIH, Bernarda Marka, do Komisji Popierania Twórczości Naukowej i Artystycznej przy PRM, z 24 października 1949 r., o finansowaniu Instytutu z dniem 1 stycznia 1950 r. ze środków budżetu państwa; Pismo dyrek- 
Pod koniec roku zmienił stanowisko, podejmując starania o wejścia „na drogę subwencji”" ${ }^{2}$. Powodem zmiany decyzji mogło być stanowisko resortu oświaty, który - odwołując się do Dekretu z dnia 28 października 1947 r. o organizacji nauki i szkolnictwa wyższego - uzależniał uwzględnienie potrzeb ŻIH w swoim budżecie od tego, czy „Instytut zostanie powołany do życia rozporządzeniem Rady Ministrów jako samodzielna placówka naukowo-badawcza podległa Ministrowi Oświaty. Utworzenie takiej placówki [...] może nastąpić w wypadku przekazania Ministerstwu zbiorów i w ogóle całego majątku rzeczonej placówki przez instytucję do tego upoważnioną" ${ }^{\prime 3}$. W 1950 r. ŻIH zdecydował się więc na pozyskiwanie środków drogą subwencji od Ministerstwa Oświaty ${ }^{64}$ (głównie na wydawanie prac naukowych, prowadzenie Archiwum i Biblioteki) oraz od MKiS (na Muzeum) ${ }^{65}$. Plan Instytutu z kwietnia $1950 \mathrm{r}$. ponownie zakładał jego upaństwowienie z dniem 1 stycznia 1951 r ${ }^{66}$ Zamiast upaństwowienia Departament Nauki Ministerstwa Oświaty - w związku z trudnościami finansowymi - zgodził się na subwencje, które miały wystarczyć na prowadzenie „normalnych prac” Instytutu ${ }^{67}$. Na ten sam sposób finansowania ŻIH zdecydowało się również $\mathrm{MKiS}^{68}$. Poza oboma resortami wpływów do kasy Instytutu dostarczały:

tora ŻIH, Bernarda Marka, do Ministra Oświaty (Departament Nauki), z 6 grudnia 1949 r., o finansowaniu Instytutu z dniem 1 stycznia 1950 r. ze środków budżetu Ministerstwa.

${ }^{62}$ AAN, MO, sygn. 3221; AŻIH, AO. Pismo dyrektora ŻIH, Bernarda Marka, do Ministerstwa Oświaty, z 27 grudnia 1949 r.

${ }_{63}$ AAN, MO, sygn. 3221. Stanowisko dyrektora Departamentu Nauki Wydziału Oświaty, wyrażone 23 grudnia 1949 r. w piśmie do ŻIH.

${ }^{64}$ Od sierpnia 1950 r. było to Ministerstwo Szkół Wyższych i Nauki.

${ }^{65}$ AŻIH, AO. Pismo dyrektora Departamentu Twórczości Artystycznej do ŻIH, z 23 marca 1950 r., w sprawie preliminarza budżetowego na 1950 r.; Pismo Naczelnego Dyrektora Muzeów i Ochrony Zabytków do Muzeum ŻIH przy CŻKP, z 21 kwietnia 1950 r., w sprawie przyznania subwencji; Komunikat dyrektora Departamentu Ministerstwa Oświaty, z 19 maja 1950 r., o przyznaniu subwencji ŻIH. W Instytucie, którego podstawę stanowiła działalność naukowo-badawcza, funkcjonowały wówczas następujące działy: archiwum, biblioteka naukowa, muzeum, galeria sztuk pięknych, kartoteka przestępców wojennych i kolaboracjonistów, wydawniczość. AAN, MO, sygn. 3221. Pismo dyrektora ŻIH, Bernarda Marka, do Ministra Oświaty (Departament Nauki), z 6 grudnia 1949 r., o finansowaniu Instytutu z dniem 1 stycznia 1950 r. ze środków budżetu Ministerstwa.

${ }_{66}$ AŻIH, AO. Pismo dyrektora ŻIH, Bernarda Marka, do Wydziału Instytutów Naukowych Departamentu Nauki Ministerstwa Oświaty, z 3 kwietnia 1950 r.

${ }^{67}$ AŻIH, AO. Pismo dyrektora Departamentu Nauki Ministerstwa Oświaty do ŻIH, z 11 lipca 1950 r., w sprawie subwencjonowania Instytutu; Pismo naczelnego dyrektora Muzeów i Ochrony Zabytków do Muzeum Historycznego Instytutu Żydowskiego przy CKŻP, z 16 maja 1950 r., w sprawie podania numeru konta do przekazywanie subwencji.

${ }_{68}$ AŻIH, AO. Pismo Kierownika Biura ŻIH, Adama Rutkowskiego, do 13. Oddziału Wydziału Finansowego Prezydium Rady Narodowej, z 7 sierpnia 1950 r., dotyczące statusu Instytutu i subwencjonowania. 
CKŻP (z funduszów likwidowanego Joint), Ziomkostwo Warszawskie, skupiające byłych żydowskich mieszkańców stolicy, oraz sprzedaż publikacji ${ }^{9}$.

Przełomowym momentem w początkowym okresie działalności Instytutu była likwidacja CKŻP, do której doszło 29 października 1950 r. na połączonej Konferencji Krajowej Przedstawicieli Komitetów Żydowskich i Żydowskiego Towarzystwa Kultury (ŻTK). W wyniku podjętej wówczas decyzji w miejsce zlikwidowanych CKŻP i ŻTK powstało Towarzystwo Społeczno-Kulturalne Żydów w Polsce (TSKŻ) ${ }^{70}$. Decyzja o rozwiązaniu CKŻP była konsekwencją rozpoczętego jeszcze w 1949 r. procesu demontażu żydowskiej autonomii narodowo-kulturalnej i upaństwowienia wchodzących w jej skład agend. Instytucje podlegające CKŻP, który w wyniku procesu „likwidacji instytucjonalnego separatyzmu” pozbawiony został instrumentów realnego oddziaływania na środowisko żydowskie, włączono do departamentów właściwych im ministerstw (te, które na mocy uchwały rządu nie przeszły na własność państwa, uległy rozwiązaniu). W wyniku likwidacji CKŻP zatem ŻIH, ,stał się instytucją samodzielną i opracował statut stowarzyszenia", który 9 grudnia 1950 r. został przesłany do Wydziału Społeczno-Administracyjnego Prezydium Stołecznej Rady Narodowej ${ }^{71}$. Opiekę nad ŻIH w zakresie subwencji sprawowały MKiS (Muzeum) oraz Ministerstwo Szkół Wyższych i Nauki (pozostałe działy). Instytut do czasu opracowania statutu zdążył jeszcze włączyć (1 listopada 1949 r.) agendy Żydowskiego Towarzystwa Krzewienia Sztuk Pięknych w Polsce (rozwiązanego 9 września tego samego roku na mocy uchwały CKŻP) $)^{72}$ oraz zlikwidować (1 maja 1950 r.) oddział w Krakowie ${ }^{73}$. Po likwidacji CKŻP Instytut przejął dokumentację oddziału i podległych mu instytucji.

${ }^{69}$ AŻIH, AO. Sprawozdanie finansowe ŻIH za okres kwiecień-sierpień 1950 r.

${ }^{70}$ AAN, sygn. 237/XXVI/34; ATSKŻ, sygn. 8/12. Protokół z posiedzenia członków założycieli TSKŻ z 29 października 1950 r. Zob. także Adelson, W Polsce zwanej Ludowa ..., s. 472.

${ }^{71}$ AŻIH, AO. Pismo dyrektora ŻIH, Bernarda Marka, do Ministerstwa Szkół Wyższych i Nauki, z 14 grudnia 1950 r., w sprawie statutu Instytutu. Por. też Maurycy Horn, Działalność naukowa Żydowskiego Instytutu Historycznego w Polsce w latach 1947-1996, [w:] Żydowski Instytut Historyczny. 50 lat działalności..., s. 44; tenże, Szkic z przeszłości Żydowskiego Instytutu Historycznego..., s. 3.

${ }_{72}$ AŻIH, AO. Pismo dyrektora ŻIH, Bernarda Marka, do Departamentu Administracyjno-Budżetowego MKiS, z 19 listopada 1949 r., w sprawie przejęcia agend Żydowskiego Towarzystwa Krzewienia Sztuk Pięknych; Pismo dyrektora ŻIH, Bernarda Marka, do Dyrekcji Banku dla Produktywizacji Żydów w Polsce w sprawie przejęcia środków finansowych po ŻTKSP, z 11 listopada $1949 \mathrm{r}$.

${ }_{73}$ AŻIH, AO. Zawiadomienie dyrektora ŻIH, złożone 13 czerwca 1950 r. do 3. Urzędu Skarbowego w Krakowie. 


\section{Towarzystwo Przyjaciół Centralnej Żydowskiej Komisji Historycznej przy CKŻP}

Centralna Żydowska Komisja Historyczna współpracowała z wieloma instytucjami zajmującymi się badaniem zbrodni hitlerowskich, nie tylko pozyskując od nich materiały i informacje, ale również udostępniając swoje (m.in. Głównej Komisji Badania Zbrodni Niemieckich). Mogła liczyć także na wsparcie organizacji społecznych. Pierwszą, która specjalnie w tym celu została powołana, było Towarzystwo Przyjaciół CŻKH przy CKŻP. Powstało ono w Łodzi w połowie października 1945 r. (zarejestrowane 17 października następnego roku ${ }^{74}$, aby „we wszelkich [...] pracach, zarówno pod względem naukowym, społecznym i materialnym" wspierać Komisję $^{75}$. W tym celu sprofilowano działalność Towarzystwa, powołując sekcje odpowiedzialne za poszczególne obszary wsparcia (zbieraniem relacji dzieci o przeżyciach okupacyjnych zajęła się sekcja pedagogiczna, natomiast opracowaniem technik do prowadzenia badań nad stanem zdrowia Żydów w okresie wojny - sekcja lekarska). Zadania kompletowania i opracowywania materiałów historycznych, organizowania odczytów, wykładów, zebrań, wystaw, utrzymania biblioteki i czytelni oraz ustanawiania stypendiów i nagród dla pracujących na polu naukowym wzięły na siebie sekcja prawnicza i komisja propagandowa. Sekcja przystąpiła do „opracowania zagadnienia teorii i praktyki prawnej hitleryzmu w stosunku do Żydów na ziemiach polskich”, natomiast komisja przeprowadziła akcję propagandową podkreślającą wagę zbierania materiałów do dziejów okupacji. Towarzystwo wydało też w listopadzie 1946 r. tom dokumentów o historii getta łódzkiego. Zadania zapisane w statucie nie znalazły jednak adekwatnego odzwierciedlenia w praktyce. W opinii niektórych członków CŻKH (np. Nachmana Blumentala) Towarzystwo nie tylko „nic nie robiło”, ale było „konkurencyjną instytucją”, która musiała „być zwalczona”76. Z powodu małej aktywności Towarzystwo na walnym zebraniu 26 stycznia 1947 r. podjęło decyzję o samolikwidacji ${ }^{77}$.

${ }^{74}$ Zarząd Towarzystwa wyłoniony został 18 listopada 1945 r. na Walnym Zebraniu. APŁ, ZMŁ, WA, sygn. 150.

${ }_{75}$ Tamże. Towarzystwo Przyjaciół CŻKH przy CKŻP.

${ }^{76}$ AŻIH, CKŻP, PiS, sygn. 303/I/20. Protokół z posiedzenia Prezydium CKŻP z 27 stycznia $1947 \mathrm{r}$.

77 APŁ, ZMŁ, WA, sygn. 150. Towarzystwo Przyjaciół CŻKH przy CKŻP. Zob. także AŻIH, CŻKH, sygn. 303/XX/23. Protokół z konferencji, odbytej 5 lutego 1947 r., w Wydziale Administracyjnym Zarządu Miejskiego w Łodzi z przedstawicielami CŻKH przy CKŻP w sprawie akt Ghettoverwaltung. 


\section{Geneza Stowarzyszenia pod nazwą „Żydowski Instytut Historyczny”}

Zgoła odmienny od Towarzystwa Przyjaciół profil działalności przyjęło stowarzyszenie nawiązujące nazwą do sukcesora CŻKH. Początki Stowarzyszenia ŻIH nie są jednak tożsame z formalnym rozpoczęciem działalności przez sam Instytut, które - jak wykazano - przypadło na 1 października $1947 \mathrm{r}$.

Stowarzyszenie uzyskało osobowość prawną (równoznaczną z zalegalizowaniem przez odpowiednie władze jego statutu) 4 września 1951 r. $^{78}$ Zanim do tego doszło, miało ono za sobą niemal rok działalności. Dotychczasowa historia Stowarzyszenia przypominała więc w pewnym sensie genezę i początkowy etap istnienia ŻIH (czy też, w zależności od przyjętej nazwy: Żydowskiego Naukowego Instytutu Historycznego lub Historycznego Instytutu Naukowego), który, choć odpowiadał głównie za naukowo-badawczy obszar działań CŻKH, nie stanowił formalnie odrębnej (mimo opracowania projektu statutu) jednostki w ramach Komisji.

Stowarzyszenie pn. „Żydowski Instytut Historyczny” powstało 8 listopada 1950 r. na Walnym Zebraniu członków założycieli Stowarzyszenia. Jego początki sięgają więc likwidacji resztek form względnej autonomii ludności żydowskiej w Polsce. Na cezurę znaczoną przekształceniami instytucji życia zbiorowego Żydów wskazywał protokół nr 1 z Walnego Zebrania:

Istniejący dotychczas Żydowski Instytut Historyczny był jednostką organizacyjnie afiliowaną przy Centralnym Komitecie Żydów w Polsce, choć faktycznie był już od dłuższego czasu instytucją całkowicie samodzielną. W związku z połączeniem się Centralnego Komitetu Żydów w Polsce z Żydowskim Towarzystwem Kultury i powstaniem [...] „Społeczno-Kulturalnego Towarzystwa Żydów w Polsce”, zachodzi konieczność - do czasu upaństwowienia Instytutu co niewątpliwie nastąpi w ciągu 1951 r. - stworzenia podstaw prawno-organizacyjnych dla samodzielnego istnienia Instytutu ${ }^{79}$.

W gronie założycieli Stowarzyszenia byli pracownicy (a zarazem współzałożyciele) Instytutu z jego dyrektorem, Bernardem Markiem, na czele,

78 APAN, sygn. II-73 W.555/XXIII. Protokół z rewizji przeprowadzonej w ŻIH przez inspektora PAN od 9 kwietnia do 14 maja 1970 r.; tamże, sygn. II-73 W.667/64. ŻIH w Polsce - dokumentacja archiwalna (1975-1978; 1988 r.). Żydowski Instytut Historyczny w Polsce (Zarys historii Instytutu i analiza jego stanu obecnego).

${ }_{79}$ ASŻIH. Protokół nr 1 z Walnego Zebrania członków założycieli Stowarzyszenia ŻIH w Polsce z siedzibą w Warszawie, z 8 listopada 1950 r.; IPN BU 1585/7394. Notatka z zebrania założycielskiego Stowarzyszenia Żydowski Instytut Historyczny z 8 listopada 1950 r. 
który dokonał otwarcia obrad i im przewodniczył. Oprócz Marka, postulującego stworzenie ,podstaw prawno-organizacyjnych dla samodzielnego istnienia Instytutu", potrzebe powołania Stowarzyszenia podniósł inny przedstawiciel ŻIH, Szymon Datner, stwierdzając, że „istnienie Instytutu [...] jest ze wszech miar konieczne i dlatego popiera powstanie tego rodzaju stowarzyszenia" ${ }^{00}$. Rezultatem podobnie formułowanych stanowisk była uchwała mówiąca, że „Żydowscy historycy, archiwiści, bibliotekarze i historycy sztuki, zebrani w dniu 8 listopada 1950 roku w Warszawie w gmachu przy ul. gen. Świerczewskiego 79, postanawiają jednomyślnie założyć stowarzyszenie pn. »Żydowski Instytut Historyczny w Warszawie «"11. Wyłoniono również Tymczasowy Komitet Organizacyjny (w składzie: Bernard Mark, Froim Kupfer i Adam Rutkowski), który został zobowiązany do zwołania zebrania mającego dokonać wyboru władz Stowarzyszenia oraz przeprowadzenia wszelkich formalności związanych z jego założeniem i legalizacją statutu.

Stowarzyszenie miało być raczej „formą przejściową” do momentu uzyskania przez ŻIH statusu państwowej placówki naukowej, który planowano osiągnąć do końca 1951 r. ${ }^{82}$

Statut, podobnie jak wniosek o założeniu Stowarzyszenia, został przyjęty jednomyślnie, choć po drobnych poprawkach (dotyczących składu liczebnego Zarządu i Komisji Rewizyjnej). W myśl jego zapisów, formułowanych pod wyraźnym wpływem ideologii marksistowskiej, do głównych celów zaliczono: (a) prowadzenie całokształtu badań nad historią Żydów oraz rozwijanie podstawy naukowej w dziedzinie historiografii „dla marksistowskiego oświetlenia całokształtu dziejów Żydów”; (b) przygotowanie i doskonalenie nowego typu kadr historyków, „,samokształcenie w dziedzinie materializmu dialektycznego i historycznego” oraz „marksistowskiej metodyki historiograficznej"; (c) wyrażanie opinii dotyczących historii Żydów, w szczególności w odniesieniu do okresu okupacji hitlerowskiej ${ }^{83}$.

Realizacja celów miała nastąpić poprzez: prowadzenie samodzielnych prac naukowo-badawczych, popularyzację wyników przeprowadzonych badań, opracowanie i redagowanie publikacji naukowych, popularyzatorskich, czasopisma (kwartalnika), biuletynów, organizowanie konferencji

80 Tamże.

81 Tamże.

82 Tamże. Zob. także: IPN BU 1585/7395. Informacja o działalności Stowarzyszenia ŻIH, z 16 czerwca 1969 r., przekazana przez zastępcę kierownika USW PRN m.st. Warszawy dyrektorowi Departamentu Społeczno-Administracyjnego MSW.

${ }_{83}$ ASŻIH. Statut Stowarzyszenia ŻIH w Polsce z siedzibą w Warszawie. 
naukowych i wykładów oraz utrzymywanie łączności z odpowiednimi instytucjami i organizacjami poza Polską.

Nakreślone cele i sposoby ich realizacji świadczą o ustanowieniu modelu zbieżności między Instytutem a powstałym dla ustanowienia podstaw prawnych jego funkcjonowania Stowarzyszeniem. Osiągnięta tożsamość była w dużym stopniu wyrazem woli założycieli ŻIH, aby zarejestrować go w takiej właśnie formie. Prowadzenie bowiem „całokształtu badań w zakresie historii Żydów”, „samodzielnych prac naukowo-badawczych” czy „opracowanie i redagowanie publikacji naukowych" to przecież zadania i środki działania wpisane w zakres kompetencyjny placówki naukowej, w jaką przekształcano wcześniej Instytut. Identyfikacja obu instytucji nastąpiła również w warstwie pojęciowej. Pośrednio, już we wstępie, informował o tym statut (rozdz. I, par. 1): „Stowarzyszenie nosi nazwę "Żydowski Instytut Historyczny w Polsce « zwany dalej »Instytutem «" $"$. Naprzemienne stosowanie nazw wystąpiło również w kolejnych częściach statutu. W rozdziale II, który dotyczył „Charakteru Stowarzyszenia, celów i środków działania”, nie padła już jednak ani razu (poza wspomnianym tytułem) nazwa „Stowarzyszenie”, natomiast pojawiło się stwierdzenie, że: „Instytut posiada osobowość prawną” (par. 5); „Celem instytutu jest [...]” (par. 6); „Instytut realizuje swe cele przez [...]” (par. 7). Nazwa „Stowarzyszenie” nie pojawiła się również w zapisach kolejnych paragrafów, w których m.in. czytamy, że: „Instytut może przyjmować zapisy i darowizny oraz nabywać i zbywać majątek ruchomy i nieruchomy [...]” (par. 8); „Członkiem Instytutu może być [...]” (rozdz. III, par. 10). Dopiero w paragrafie 11 powiedziane zostało, że „Członkostwo [w Instytucie - przyp. A.R.] nabywa się przez złożenie deklaracji przystąpienia do Stowarzyszenia i przyjęcie przez Zarząd Główny”. Dalej (par. 14) czytamy też, że „członkostwo [w Instytucie - przyp. A.R.] gaśnie m.in. przez likwidację Stowarzyszenia" ${ }^{85}$. W przywołanych zapisach statutowych Instytut i Stowarzyszenie zostały więc potraktowane w sposób tożsamy.

W kolejnych rozdziałach punkt ciężkości w posługiwaniu się nazwą instytucji przeniesiony został na Stowarzyszenie. $Z$ ich treści wynika, że władzami Stowarzyszenia były: Walne Zgromadzenie, Zarząd Główny i Główna Komisja Rewizyjna. Walne Zgromadzenie członków było najwyższą władzą Stowarzyszenia. Wybierało ono Zarząd Główny, na którego

${ }^{84}$ Zgodnie z ujęciem stosowanym powszechnie w statutach skrót przy tak brzmiącym zapisie powinien się odnosić do nazwy „Stowarzyszenie”. Użycie zwrotu „zwany dalej »Instytutem «" informuje, że ten termin będzie równoznaczny z określeniem „Stowarzyszenie”.

85 Zob. przyp. 83. 
czele stał - wybierany z grona jego członków - prezes. Był on jednocześnie dyrektorem Instytutu kierującym całością prac naukowo-badawczych i organizacyjno-administracyjnych tej placówki ${ }^{86}$. Zarząd Główny powoływał Radę Naukową Instytutu, której przewodniczący był dyrektorem Instytutu (czyli prezesem Zarządu Głównego Stowarzyszenia).

Wszelkie związane z założeniem Stowarzyszenia formalności, które komitet organizacyjny zobowiązał się przeprowadzić, zostały dopełnione w pierwszej połowie września $1951 \mathrm{r}$. Zatem już 4 września tego roku w Wydziale Społeczno-Administracyjnym Prezydium Rady Narodowej w Warszawie Stowarzyszenie uzyskało rejestrację na podstawie przedłożonego statutu, natomiast na mocy decyzji z 13 września 1951 r. ŻIH został wpisany do Rejestru Stowarzyszeń i Związków Urzędu Spraw Wewnętrznych Prezydium Rady Narodowej m.st. Warszawy ${ }^{87}$.

Po uregulowaniu sytuacji prawnej Instytut, jako jedno z towarzystw naukowych, uzyskał afiliację przy - powstałej w tym samym roku - Polskiej Akademii Nauk ${ }^{88}$. Akademia (Wydział I) stała się tym samym główną instytucją odpowiedzialną za dotowanie ŻIH i sprawowanie nad nim merytorycznego nadzoru. Wysokość dotacji, których przyznawanie PAN rozpoczęła dopiero w 1953 r., była uzależniona od subwencji dla ŻIH z innych źródeł, jego zasobów własnych i potrzeb ${ }^{89}$.

Warto nadmienić, że do wydawanego przez Instytut „Bleter far Geszichte" (od 1955 r. w postaci półrocznika) dołączył wychodzący od 1950 r. - początkowo nieregularnie, następnie (od 1951 r.) jako półrocznik i wreszcie (od 1953 r.) jako rocznik - „Biuletyn Żydowskiego Instytutu Historycznego".

W początkowym okresie działalności Stowarzyszenie ŻIH skupiało ok. 100 członków ${ }^{90}$.

${ }^{86}$ W Statucie dopisano również (odręcznie), że kierowanie Instytutem przez prezesa ma się odbywać w ścisłym porozumieniu z Departamentem Nauki Ministerstwa Szkół Wyższych i Nauki oraz ze Zrzeszeniem Społeczno-Kulturalnym Żydów w Polsce (chodziło tu oczywiście o powstałe w 1950 r. Towarzystwo Społeczno-Kulturalne Żydów w Polsce).

${ }^{87}$ APAN, sygn. II-73 W.555/XXIII. Protokół z rewizji przeprowadzonej w ŻIH przez inspektora PAN od 9 kwietnia do 14 maja 1970 r.

88 Tamże, sygn. II-73 W.667/64. ŻIH w Polsce - dokumentacja archiwalna (1975-1978; 1988 r.). Żydowski Instytut Historyczny w Polsce (Zarys historii Instytutu i analiza jego stanu obecnego).

${ }^{89}$ Tamże, sygn. II-73 W.555/XXIII. Notatka o ŻIH sporządzona przez jego dyrektora, Artura Eisenbacha, 7 czerwca 1968 r.

${ }^{90}$ IPN BU 1585/7395. Informacja o działalności Stowarzyszenia ŻIH, z 16 czerwca 1969 r., przekazana przez zastępcę kierownika USW PRN m.st. Warszawy dyrektorowi Departamentu Społeczno-Administracyjnego MSW. 


\section{Instytut a Stowarzyszenie w świetle statutu z 1964 roku}

Znaczącego wpływu na działalność Instytutu nie wywarła silna artykulacja haseł antysemickich z drugiej połowy lat pięćdziesiątych XX w., wywołana rozgrywkami wewnątrzpartyjnymi o przejęcie przez nieformalne grupy komunistycznych aparatczyków kontroli nad społeczeństwem. Skierowanie rozliczeń za autoryzowanie okresu „błędów i wypaczeń” końca lat czterdziestych i pierwszej połowy następnej dekady na niejednokrotnie już ubite tory antyżydowskich emocji miało również skanalizować narastające w kraju niezadowolenie społeczne. Metoda posługiwania się nienawistną retoryką rozbudziła tkwiące w części społeczeństwa uprzedzenia wobec Żydów, które uległy wyzwoleniu w początkowej fazie tzw. odwilży październikowej, gdy nastroje społecznego niezadowolenia były artykułowane w sposób niemal nieskrępowany. Mimo wzrostu nastrojów antysemickich i towarzyszących im administracyjnych ułatwień w opuszczeniu kraju - których efektem była emigracja z Polski w latach 1956-1960 ok. 48 tys. Żydów (bądź też Polaków żydowskiego pochodzenia) ${ }^{91}$ - Instytut nie zahamował dość intensywnej, a rozpoczętej zaledwie dekadę wcześniej działalności. Liczba członków Stowarzyszenia - utrzymująca się od początku jego działalności na poziomie 100 osób (z małymi wahaniami) - w wyniku wyjazdu części z nich do Izraela spadła jednak w 1958 r. poniżej 70 osób $^{92}$.

Nikłym echem w środowisku ŻIH odbiło się na początku następnej dekady wprowadzenie Ustawy z dnia 17 lutego 1961 r. o instytutach naukowo-badawczych, która regulowała m.in. tryb zatrudniania pracowników naukowych w instytutach nieposiadających dotąd takich uprawnień. Brak reakcji ze strony Instytutu (wyrażającej się podjęciem starań o włączenie w poczet tych jednostek) wpływał na jego nieustabilizowaną sytuacją prawną jako stowarzyszenia naukowego ${ }^{93}$.

${ }^{91}$ Krzysztof Lesiakowski, Emigracja osób pochodzenia żydowskiego z Polski w latach 1968-1969, „Dzieje Najnowsze” (1993), nr 2, s. 119; Rykała, Przemiany sytuacji społeczno-politycznej mniejszości żydowskiej..., s. 209.

${ }_{92}$ Zob. przyp. 90.

${ }_{93}$ Nieuregulowana sytuacja prawna ŻIH, powodująca upośledzenie pracowników pod względem płacowym i uprawnień socjalnych w porównaniu z innymi towarzystwami naukowymi afiliowanymi przy PAN, należała do głównych przyczyn (oprócz przeciążenia naukowców pracą administracyjną i techniczną) spadku efektywności pracy Instytutu i braku awansów naukowych. Horn, Szkic z przeszłości Żydowskiego Instytutu Historycznego..., s. 10; tenże, Działalność Żydowskiego Instytutu Historycznego w Polsce w latach 1967-1979, „Biuletyn ŻIH" (1979), nr 3, s. 7. 
W 1963 r. Zarząd ŻIH na posiedzeniu odbytym 11 stycznia uchwalił natomiast strukturę i regulamin wewnętrzny Instytutu. Nie naruszały one struktury prawno-organizacyjnej Stowarzyszenia, a jedynie doprecyzowywały funkcjonowanie poszczególnych składowych placówki naukowo-badawczej. Poza potwierdzeniem statutowego zapisu, że całokształtem prac ŻIH „kieruje dyrektor, wybierany przez Zarząd ŻIH”, w uchwalonej strukturze wyszczególniono trzy działy wchodzące w skład Instytutu: Archiwum, Dział Muzealny i Bibliotekę. Służyły one „w pierwszym rzędzie potrzebom badawczym pracowników ŻIH”, choć ich zasoby mogły być „udostępniane na ogólnie przyjętych zasadach pracownikom naukowym i badaczom spoza ŻIH" (pkt 4) ${ }^{94}$. W regulaminie natomiast znalazły umocowanie m.in.: zadania kierowników (pkt 5) i pracowników (pkt 6) poszczególnych działów, powinności zespołu naukowego (pkt 6) i organizacja prac wydawniczych Instytutu (pkt 9) ${ }^{95}$.

W roku uchwalenia struktury i regulaminu wewnętrznego ŻIH wśród osób zaangażowanych w jego działalność zarysowały się tendencje zmierzające do oddzielenia Instytutu - jako placówki naukowej od Stowarzyszenia. Zwolennicy separacji uzasadniali swoje stanowisko wzrastającą rolą Instytutu i potrzebą podejmowania nowych wyzwań naukowo-badawczych ${ }^{96}$.

Urząd Spraw Wewnętrznych Prezydium Rady Narodowej m.st. Warszawy zatwierdził 3 kwietnia 1964 r. zmiany statutu Stowarzyszenia ŻIH w Polsce uchwalone 26 stycznia 1964 r. na Walnym Zebraniu ${ }^{97}$. Statut, „stanowiący podstawę prawną działalności Instytutu"98, potwierdził, że ŻIH prowadzi działalność w formie stowarzyszenia. Poza niewielkimi zmianami w stosunku do statutu z 1951 r. zachowano w nim m.in. przemienność w stosowaniu nazw: „Stowarzyszenie” i „ŻIH”.

W obu statutach zapisane zostało, że Instytut „posiada osobowość prawną”, przy czym w statucie z 1964 r. zwrot ten ujęty był w szerszą formułę, a mianowicie: „Żydowski Instytut Historyczny jest stowarzyszeniem

94 APAN, sygn. II-73 W.555/XXIII; AAN, NIK 42/101. Struktura ŻIH uchwalona przez Zarząd 11 stycznia $1963 \mathrm{r}$.

${ }_{95}$ Tamże. Regulamin ŻIH uchwalony przez Zarząd 11 stycznia $1963 \mathrm{r}$.

96 Zob. przyp. 90.

${ }^{97}$ IPN BU 1585/7360; ASŻIH. Decyzja USW PRN m.st. Warszawy o zatwierdzeniu zmian w statucie ŻIH. Zob. także APAN, sygn. II-73 W.555/XXIII. Protokół z rewizji przeprowadzonej w ŻIH przez inspektora PAN od 9 kwietnia do 14 maja 1970 r. W decyzji zatwierdzającej zmiany statutu była mowa o ŻIH.

98 APAN, sygn. II-73 W.555/XXIII. Protokół z kontroli przeprowadzonej w ŻIH przez inspektora PAN od 2 do 15 grudnia $1971 \mathrm{r}$. 
zarejestrowanym i posiada osobność prawną" (art. 2) ${ }^{99}$. W ten sposób powiedziane zostało wprost, że ŻIH to stowarzyszenie. W obu przypadkach posiadanie osobowości prawnej przez ŻIH należało utożsamiać $\mathrm{z}$ nabyciem jej przez Stowarzyszenie (na podstawie zalegalizowania statutu).

W statucie z 1964 r., podobnie jak we wcześniejszym z 1951 r., w części (rozdz. II) wyjaśniającej charakter, cele i środki działania [Stowarzyszenia - przyp. A.R.] posługiwano się jednak wyłącznie nazwą „Instytut”. W przyjętym akcie pojawiły się również nowe zapisy, w których stwierdzono, że ŻIH ,jest placówką naukowo-badawczą pod opieką Polskiej Akademii Nauk” (art. 5) oraz że „opiera swą działalność na pracy społecznej swych członków". To drugie stwierdzenie wskazywało pośrednio na ścisły związek między Instytutem i Stowarzyszeniem, tym razem poprzez pewne odwrócenie relacji - choć z nazwy przywołany był Instytut, to należało go identyfikować ze Stowarzyszeniem jako ciałem społecznym. Aspekt pozbawionej materialnych motywacji działalności na rzecz Instytutu wynikający na ogół z istoty funkcjonowania stowarzyszeń - podjęty był również w art. 12: „Członkowie zobowiązani są do [...] pracy społecznej na rzecz Żydowskiego Instytutu Historycznego”, oraz w art. 13: „Pełnienie funkcji we władzach stowarzyszenia (Zarząd i Komisja Rewizyjna) jest honorowe" $" 100$.

Przetasowania w nomenklaturze dotyczyły również kwestii członkostwa: w statucie z 1951 r. droga do jego nabycia wiodła, jak wspomniano, przez złożenie deklaracji przystąpienia do Stowarzyszenia, a następnie przyjęcie przez Zarząd Główny; w regulacji z 1964 r. - „przez złożenie deklaracji z prośbą o przyjęcie, które winno być zaaprobowane i zatwierdzone przez zarząd Żydowskiego Instytutu Historycznego" (art. 10) ${ }^{101}$. Należy zauważyć, że w obu przypadkach (zarówno w odniesieniu do Stowarzyszenia, jak i Instytutu) chodziło o ten sam organ (Zarząd).

Różnice między oboma statutami, wynikające ze zmiany relacji między odwołaniami do nazw „Stowarzyszenie” i „Instytut”, dotyczyły również zapisów regulujących strukturę władzy. W statucie z 1964 r. Walne Zebranie członków, Zarząd i Komisja Rewizyjna były „Organami Żydowskiego Instytutu Historycznego" (rozdz. IV, art. 16), natomiast w statucie z 1951 r. Walne Zgromadzenie, Zarząd Główny i Główną Komisję Rewizyjną określano jako „Władze Stowarzyszenia” (rozdz. IV, par. 15). Warto

\footnotetext{
${ }^{99}$ ASŻIH. Statut Stowarzyszenia pod nazwą „Żydowski Instytut Historyczny”.

100 Tamże.

101 Tamże.
} 
dodać, że do kompetencji „Najwyższego organu Żydowskiego Instytutu Historycznego", jakim było Walne Zebranie, należało podjęcie uchwały „w sprawie rozwiązania Stowarzyszenia” (art. 20 lit. e) oraz „w sprawie zmiany statutu Żydowskiego Instytutu Historycznego” (art. 20 lit. d) ${ }^{102}$. Znamienne w kontekście tych rozważań jest to, że poza pierwszym rozdziałem nazwa „Stowarzyszenie” pojawiła się w nowym statucie dopiero w tytule ostatniego (rozdz. VII), w którym podjęto kwestię rozwiązania Stowarzyszenia (art. 36). Przemienność w posługiwaniu się nazwami: „ŻIH” i „Stowarzyszenie”, nie pozostawia wątpliwości, że wyrażały one jedną formę organizacyjno-prawną.

W statucie z 1964 r., podobnie jak w jego odpowiedniku z 1951 r., przewodniczący (w 1951 r. prezes) Zarządu - wybieranego przez Walne Zgromadzenie - był jednocześnie dyrektorem ŻIH (art. 25 lit. b). Pełniący to stanowisko przewodniczył także Radzie Naukowej (art. 28) ${ }^{103}$.

W kontekście sprawowania tych funkcji warto przypomnieć art. 5, według którego Instytut (jako placówka naukowo-badawcza) działał „pod opieką Polskiej Akademii Nauk” (Wydział I, Nauki Społeczne). „Opieka” oznaczała, że uzgodnienia z Akademią wymagał wybór dyrektora ŻIH (art. 25 lit. c). Porozumienia z PAN wymagało też kierowanie przez dyrektora całokształtem prac naukowo-badawczych i organizacyjno-administracyjnych ŻIH (art. 25 lit. d) oraz powołanie przez Zarząd Rady Naukowej ŻIH (art. 28). Subwencje przekazywane przez Akademię stanowiły także podstawowe źródło funduszy Instytutu (art. 33).

\section{Pod opieką Polskiej Akademii Nauk - Żydowski Instytut Historyczny jako placówka naukowo-badawcza i społeczna}

Polska Akademia Nauk, zgodnie z postanowieniami statutu ŻIH oraz ustawowymi i statutowymi zadaniami Akademii (art. 2 Ustawy z dnia 17 lutego 1960 r. o Polskiej Akademii Nauk i z późniejszymi zmianami, par. 21 pkt 6 jej statutu), sprawowała opiekę nad Instytutem ${ }^{104}$. W praktyce

102 Tamże.

${ }_{103}$ Tamże.

104 APAN, sygn. II-73 W.555/XXIII. Notatka wiceprezesa NIK dla sekretarza naukowego PAN z 21 lutego 1968 r.; ASŻIH. Protokół kontroli przeprowadzonej w ŻIH, od 13 lipca do 18 września 1987 r., przez specjalistę Biura Kontroli PAN. Kompetencje kontrolowania działalności gospodarczej ŻIH oraz przestrzegania przez Stowarzyszenie przepisów i obowiązków wynikających z postanowień statutu przypisywał sobie Urząd Spraw Wewnętrz- 
dotowała jego działalność, natomiast nie pełniła nad nim merytorycznego nadzoru $^{105}$. Z jednej strony bowiem Instytut nie przedkładał Akademii szczegółowych planów naukowo-badawczych, z drugiej - Akademia nie tylko nie żądała tego od Instytutu, ale też nie formułowała pod jego adresem innych postulatów dotyczących prowadzonej działalności ${ }^{106}$. Opiekuńcza rola PAN sprowadzała się więc w zasadzie do formalnego zatwierdzania preliminarzy budżetowych i przekazywania środków finansowych ${ }^{107}$. Najbardziej chyba wymiernym potwierdzeniem braku kontroli był niespełniony od daty powstania ŻIH i ukonstytuowania się jego naczelnych organów (październik 1947 r.) statutowy warunek powołania Rady Naukowej. W zakres jej kompetencji wpisano omawianie „zagadnień naukowych”, mających przecież zasadnicze znaczenie dla działalności Instytutu, oraz wypowiadanie się w sprawach planów naukowo-badawczych (art. 28).

Należy przyjąć, że ŻIH stanowił placówkę społeczną utrzymywaną w zasadzie z budżetu państwa za pośrednictwem PAN. Dotacje dla Instytutu pochodziły z puli dotacji przyznawanych przez Akademię towarzystwom naukowym („organizacjom społecznym”) ${ }^{108}$. Kwalifikowanie natomiast pracowników administracji i „obsługi” do odpowiednich stanowisk i grup

nych. IPN BU 1585/7367. Notatka o Żydowskim Instytucie Historycznym z 6 października 1965 r. (brak podpisu pod dokumentem).

${ }_{105}$ Poza dotacją PAN Instytut otrzymywał subsydia z Centralnej Żydowskiej Komisji Pomocy Społecznej (CŻKPS) i TSKŻ oraz wpływy w postaci „,zagranicznych środków płatniczych” za usługi świadczone dla osób prywatnych. Uzyskiwał również pomoc finansową z Departamentu Prasy i Informacji Ministerstwa Spraw Zagranicznych w drodze prenumeraty „Biuletynu ŻIH”. Warto nadmienić, że periodyk ten wydawany był na koszt Instytutu, natomiast „Bleter far Geszichte” - ze środków wydawnictwa Idisz Buch należącego do TSKŻ. APAN, sygn. II-73 W.555/XXIII. Informacja NIK dla sekretarza Wydziału I Nauk Społecznych PAN z 20 lutego 1968 r.; IPN BU 1585/7231. Zawiadomienie wystosowane 1 marca 1967 r. do ŻIH przez Zarząd Główny TSKŻ o wyasygnowania środków finansowych przez Towarzystwo na działalność Instytutu; Pismo dyrektora ŻIH, Artura Eisenbacha, do Prezydium ZG TSKŻ, z 3 stycznia 1968 r., w sprawie przekazania dotacji na prowadzenie prac naukowych.

106 AAN, NIK 42/101. Wyjaśnienia dyrektora ŻIH, Artura Eisenbacha, dla NIK, z 30 listopada 1967 r.; Informacja o wynikach kontroli przeprowadzonej przez NIK w ŻIH w IV kwartale $1967 \mathrm{r}$.

107 APAN, sygn. II-73 W.555/XXIII. Informacja NIK dla sekretarza Wydziału I Nauk Społecznych PAN z 20 lutego 1968 r.; Notatka wiceprezesa NIK dla sekretarza naukowego PAN z 21 lutego 1968 r. Kontrola sprawowana nad ŻIH przez PAN została oceniona bardzo negatywnie przez dyrektora Zespołu Oświaty, Nauki i Kultury NIK, Jana Dominiewskiego, w piśmie, wystosowanym 20 lutego 1968 r., do sekretarza Wydziału I PAN, Stefana Żółkiewskiego. Zob. także: Tadeusz P. Rutkowski, Żydowski Instytut Historyczny i jego pracownicy w okresie wydarzeń marcowych 1968 r., „Dzieje Najnowsze” (2011), nr 4, s. 35.

108 AAN, NIK 42/101. Wyjaśnienie naczelnika Oddziału Budżetowego PAN, z 11 kwietnia 1969 r., w związku z żądaniem kontroli NIK. 
uposażenia dokonywane było na podstawie postanowienia zarządzenia Sekretarza Naukowego PAN, z 17 stycznia 1967 r., w sprawie zasad wynagrodzenia pracowników zatrudnionych w towarzystwach naukowych dotowanych przez Akademię ${ }^{109}$.

Objęcie ŻIH większym nadzorem ze strony Akademii nastąpiło w roku 1968 - przełomowym dla całego środowiska żydowskiego w Polsce ${ }^{110}$. Mimo sugestii Najwyższej Izby Kontroli (NIK) o rozważeniu celowości dalszego dotowania Instytutu ${ }^{111}$ Wydział I PAN w kwietniu tego roku opowiedział się „,za utrzymaniem ŻIH jako placówki naukowo-badawczej”, podejmując jednak zarówno „wstępne kroki stanowiące zapowiedź pewnych posunięć organizacyjnych”, jak i „daleko idące zmiany organizacyjne” ${ }^{112}$. Na mocy uchwały Sekretariatu Naukowego Wydziału I Nauk Społecznych PAN z 11 czerwca 1969 r. powołano Radę Naukową ŻIH ${ }^{113}$. Przewodniczącym

${ }^{109}$ IPN BU 1585/1402; APAN, sygn. II-73 W.555/XXIII. Protokół z kontroli przeprowadzonej w ŻIH przez inspektora PAN od 15 lutego do 24 marca 1973 r.

${ }^{110}$ W styczniu $1968 \mathrm{r}$. na podstawie decyzji MSW dotacja TSKŻ dla ŻIH została wstrzymana. Wprowadzenie tych ograniczeń, mimo poparcia Wydziału I PAN i Zakładu Historii Partii przy Komitecie Centralnym (KC) Polskiej Zjednoczonej Partii Robotniczej (PZPR) dla utrzymania dotychczasowej formy finansowania Instytutu, Ministerstwo tłumaczyło tym, że ŻIH jako jednostka dotowana przez PAN nie mógł być, zgodnie z Rozporządzeniem Rady Ministrów z 28 lipca 1959 r. w sprawie udzielania dotacji budżetowych organizacjom społecznym, dotowany z innego źródła (par. 5). Towarzystwo nie było uprawnione do przekazywania na rzecz ŻIH jakichkolwiek kwot, ponieważ - zgodnie z wymienionym Rozporządzeniem (par. 12) - będąc dotowaną organizacją społeczną, nie mogło tym samym udzielać innym organizacjom społecznym dotacji lub pomocy materialnej. IPN BU 1585/7231. Notatka, z 31 stycznia 1968 r., dotycząca pisma ŻIH do ZG TSKŻ (z 3 stycznia 1968 r.) w sprawie przekazania dotacji na prowadzenie prac naukowych; Pismo dyrektora Departamentu Społeczno-Administracyjnego MSW do wiceministra resortu z 31 stycznia 1968 r. w sprawie nieudzielania przez TSKŻ dotacji dla ŻIH; Pismo Wydziału I PAN do Prezydium ZG TSKŻ, z 8 stycznia 1968 r., w sprawie poparcia dotacji Towarzystwa dla ŻIH; Pismo Zakładu Historii Partii przy KC PZPR do Prezydium ZG TSKŻ, z 11 stycznia 1968 r., w sprawie poparcia dotacji Towarzystwa dla ŻIH. Zob. Rutkowski, Żydowski Instytut Historyczny $i$ jego pracownicy..., s. 32. Zaprzestanie dotowania ŻIH przez TSKŻ (przekazującego na ten cel głównie środki otrzymywane z zagranicy) znacznie pogorszyło sytuację finansową Instytutu. Horn, Działalność Żydowskiego Instytutu Historycznego w Polsce w latach 1967-1979..., s. 7.

${ }^{111}$ APAN, sygn. II-73 W.555/XXIII. Notatka dla Sekretarza Naukowego PAN w sprawie ŻIH z 11 grudnia 1969 r.; Informacja NIK dla sekretarza Wydziału I Nauk Społecznych PAN z 20 lutego 1968 r.; Notatka wiceprezesa NIK dla sekretarza naukowego PAN z 21 lutego $1968 \mathrm{r}$.

112 AAN, NIK 42/101. Uwagi NIK do odpowiedzi ŻIH i Wydziału I Nauk Społecznych PAN z 26 marca i 22 kwietnia $1968 \mathrm{r}$.

113 APAN, sygn. II-73 W.667/64. ŻIH w Polsce - dokumentacja archiwalna (1975-1978; 1988 r.). Żydowski Instytut Historyczny w Polsce (Zarys historii Instytutu i analiza jego stanu obecnego); ASŻIH. Protokół z kontroli przeprowadzonej w ŻIH przez inspektora PAN od 2 do 15 grudnia 1971 r.; APAN, sygn. II-73 W.555/XXIII. Protokół z kontroli przeprowa- 
Rady nie został jednak - jak przewidywał statut - dyrektor Instytutu, lecz mianowany przez PAN prof. Stanisław Herbst ${ }^{114}$.

Ze strony Akademii (sekretarza Wydziału I) pojawiły się w tym czasie sugestie pod adresem ŻIH, by ten wystąpił do Komitetu Nauki i Techniki, w trybie ustalonym przepisami art. 39 Ustawy z dnia 17 lutego $1961 \mathrm{r}$. o instytutach naukowo-badawczych ${ }^{115}$, w sprawie ewentualnego objęcia go wykazem jednostek organizacyjnych, w których mogą być zatrudniani pracownicy naukowo-badawczy. W opinii PAN Instytut nie miał w zasadzie podstaw do zatrudniania tej kategorii pracowników (których, zwłaszcza w pismach adresowanych do Akademii, tytułowano ,adiunktami”, „starszymi asystentami”, „asystentami”) ${ }^{116}$. W efekcie podjętych starań, na mocy zarządzenia nr 63 Przewodniczącego Komitetu Nauki i Techniki z 29 października 1969 r., ŻIH został włączony w poczet jednostek organizacyjnych uprawnionych do zatrudniania pracowników naukowych ${ }^{117}$.

\section{Zmiany organizacyjne w Żydowskim Instytucie Historycznym pod wpływem wydarzeń Marca '68}

Pierwszym dyrektorem ŻIH, stojącym na czele Zarządu Instytutu powołanego jeszcze (16 października 1947 r.) przez CKŻP, był Nachman Blumental. W „okresie statutowym” funkcje przewodniczącego (do 1964 r. prezesa) Zarządu, a jednocześnie dyrektora Instytutu sprawowali kolejno: Bernard Mark (1 września 1949 r. - 4 lipca 1966 r. $)^{118}$, Artur Eisenbach

dzonej w ŻIH przez inspektora PAN od 15 lutego do 24 marca 1973 r. Wprawdzie Zarząd i Dyrekcja ŻIH podjęly w tym czasie pewne kroki mające na celu powołanie Rady Naukowej, stanowiącej niezbędny warunek uzyskania przez Instytut uprawnień do zatrudniania (i mianowania) na stanowiskach asystentów i adiunktów pracowników naukowych, ale podczas kadencji dyrektora Artura Eisenbacha nie przyniosły one praktycznych rezultatów. Horn, Działalność Żydowskiego Instytutu Historycznego w Polsce w latach 1967-1979..., s. 7.

114 IPN BU 1585/7362. Uchwała Sekretariatu Naukowego Wydziału I Nauk Społecznych PAN, z 11 czerwca 1969 r., w sprawie powołania Rady Naukowej ŻIH na okres 19691971.

115 Dz.U. z 1965 r. Nr 19, poz. 129.

116 APAN, sygn. II-73 W.555/XXIII. Notatka z rozmowy przeprowadzonej 3 maja 1968 r. między p.o. sekretarza Wydziału I PAN i dyrektorem ŻIH w sprawie wniosków pokontrolnych NIK dotyczących ŻIH.

117 APAN, sygn. II-73 W.555/XXIII. Notatka służbowa w sprawie powołania Rady Naukowej w ŻIH, sporządzona 5 maja 1972 r.

${ }_{118}$ Bernard Mark do czasu powołania Stowarzyszenia pełnił funkcję dyrektora Instytutu również na mocy decyzji CKŻP. W związku z chorobą Bernarda Marka Zarząd ŻIH na posiedzeniu 8 kwietnia 1966 r. zlecił kierowanie całością prac Instytutu w okresie przejściowym Arturowi Eisenbachowi i Adamowi Rutkowskiemu w charakterze zastępców dy- 
(17 października 1966 r. - 28 czerwca 1968 r.) ${ }^{119}$ i Adam Rutkowski (prawdopodobnie od końca czerwca do 10 października 1968 r.) ${ }^{120}$.

Sprawowanie tylko przez niespełna dwa lata funkcji dyrektora przez prof. Eisenbacha spowodowane było tzw. wydarzeniami marcowymi z 1968 r., które przybrały znamiona brutalnej, państwowej - choć podchwyconej przez część społeczeństwa - nagonki antysemickiej, w wyniku której do wyjazdu z kraju zmuszonych zostało co najmniej 12 tys. osób pochodzenia żydowskiego. Na fali tej swoistej czystki etnicznej - zapoczątkowanej jeszcze, jak stwierdziła Alina Cała, ,deportacjami przeprowadzonymi przez hitlerowców, a zakończonej ekspulsją Żydów z Polski w 1968 r." 121 - władze państwa próbowały doprowadzić nawet do likwidacji Instytutu w jego ówczesnym kształcie. Polska Akademia Nauk, w osobie p.o. sekretarza jej Wydziału I, Tadeusza Cieślaka, sugerowała, aby Instytut przekazał swoje archiwum odpowiednim instytucjom (np. archiwom państwowym, muzeom, Głównej Komisji Badania Zbrodni Hitlerowskich w Polsce), zbiory biblioteczne zdeponował w Bibliotece Narodowej, a w swoich zasobach pozostawił jedynie podręczną bibliotekę. Sekretarz PAN podkreślał tym samym, że opieka ze strony Akademii powinna dotyczyć tylko „zagadnień naukowo-badawczych”122. Propozycje

rektora. APAN, sygn. II-73 W.555/XXIII. Protokół z kontroli ŻIH przeprowadzonej przez doradcę ekonomicznego Zespołu Oświaty, Nauki i Kultury NIK od 8 sierpnia do 25 listopada 1967 r.; Protokół rewizji przeprowadzonej w ŻIH przez inspektora PAN od 9 kwietnia do 14 maja $1970 \mathrm{r}$.

119 IPN BU 1585/7369. Odpisy rezygnacji Artura Eisenbacha z funkcji dyrektora ŻIH, przesłane 19 czerwca 1968 r. do Zarządu ŻIH i Prezydium TSKŻ; APAN, sygn. II-73 W.555/ XXIII. Protokół z kontroli przeprowadzonej w ŻIH przez doradcę ekonomicznego Zespołu Oświaty, Nauki i Kultury NIK od 8 sierpnia do 25 listopada 1967 r.

${ }_{120}$ ASŻIH. Protokół z posiedzenia Zarządu ŻIH z 30 września 1968 r.; AAN, NIK 42/101. Protokół z kontroli przeprowadzonej w ŻIH przez doradcę ekonomicznego Zespołu Oświaty, Nauki i Kultury NIK od 8 sierpnia do 25 listopada 1967 r.; Protokół z rewizji przeprowadzonej w ŻIH przez inspektora PAN od 9 kwietnia do 14 maja $1970 \mathrm{r}$.

${ }^{121}$ Alina Cała, Ochrona bezpieczeństwa fizycznego Żydów w Polsce powojennej. Komisje Specjalne przy Centralnym Komitecie Żydów w Polsce, Warszawa 2014, s. 27.

${ }_{122}$ APAN, sygn. II-73 W.555/XXIII. Notatka z rozmowy przeprowadzonej 3 maja 1968 r. między p.o. sekretarza Wydziału I PAN i dyrektorem ŻIH w sprawie wniosków pokontrolnych NIK dotyczących ŻIH; Notatka dla Sekretarza Naukowego PAN w sprawie ŻIH, z 11 grudnia 1969 r.; Odpowiedź zastępcy sekretarza Wydziału I PAN, z 21 grudnia 1967 r., skierowana do NIK w sprawie kontroli w ŻIH; AAN, NIK 42/101. Odpowiedź sekretarza Wydziału I PAN, z 22 kwietnia 1968 r., skierowana do NIK w sprawie kontroli w ŻIH. Komitet Nauk Historycznych PAN oraz zastępca sekretarza Wydziału I PAN, prof. Czesław Madajczyk, zalecali również, żeby ŻIH skupiał badaczy, opierając się na kryterium kompetencyjnym, nie zaś narodowościowym (mającym rzekomo sprzyjać dyskryminacji osób innego pochodzenia etnicznego), oraz żeby nie ograniczał się do badań historycznych, lecz poszerzył je o problematykę socjologiczną i kultury żydowskiej. Opinie Komitetu i se- 
Wydziału I PAN można więc interpretować jako próbę przekształcenia ŻIH w instytut naukowo-badawczy, na wzór innych towarzystw naukowych działających w Polsce, pozbawiony jednakże trzech zasadniczych dla jego funkcjonowania działów: archiwalnego, muzealnego i bibliotecznego ${ }^{123}$.

Opór kierownictwa ŻIH wobec wysuwanych postulatów odwlekał ich realizację. Do rozparcelowania zbiorów ostatecznie nie doszło ${ }^{124}$, do czego w dużym stopniu przyczynili się reprezentanci środowiska naukowego, sprzeciwiający się tak daleko idącej ingerencji w sprawy wyjątkowej w skali kraju placówki, oraz próby wyciszenia przez władze państwowe kampanii „antysyjonistycznej”"125.

Stanowczy sprzeciw wobec zabiegów prowadzących do zmarnotrawienia dorobku instytucji zasłużonej dla historii i kultury żydowskiej, na jaki zdobyły się władze ŻIH, okupiony został dymisją, odwołaniem ze stanowiska oraz zwolnieniem z pracy Artura Eisenbacha ${ }^{126}$. Choć placówka, dzięki m.in. jego nieugiętej postawie i odwadze, przetrwała, popadła w „głęboki kryzys”, zwłaszcza na polu badań naukowych. Atmosfera nagonki antysemickiej bardzo silnie wpłynęła na nastroje panujące w Instytucie, powodując „odejścia do innej pracy i emigrację prawie wszystkich pozostałych pracowników"127. Wiele osób (w tym profesorów

kretarza zawierały ponadto sugestie powiązania planów naukowych Instytutu z całokształtem badań prowadzonych w Polsce, które miały zapewnić traktowanie historii Żydów jako integralnej części polskiego procesu dziejowego. Rutkowski, Żydowski Instytut Historyczny i jego pracownicy..., s. 39-41.

${ }^{123}$ Horn, Działalność Żydowskiego Instytutu Historycznego w Polsce w latach 1967$1979 \ldots$, s. 7-8.

${ }^{124}$ Zarząd ŻIH zgodził się jedynie na przekazanie wojewódzkim archiwom państwowym depozytów złożonych przez nie w swoim czasie w Instytucie, oświadczając przy tym, że zgodnie ze statutem o losie pozostałych archiwaliów może zdecydować jedynie Walne Zgromadzenie członków Stowarzyszenia. Pierwsze partie materiałów z depozytów zostały zwrócone ich właścicielom w trzeciej dekadzie czerwca 1968 r. - zob. tamże, s. 9. Od 21 czerwca 1968 r. do 11 lutego 1969 r. przekazano Archiwum Państwowemu w Łodzi zespoły archiwalne dotyczące miejscowego getta. IPN BU 1585/7382. Odpis pisma dyrektora Archiwum Państwowego m. Łodzi i Województwa Łódzkiego do Naczelnej Dyrekcji Archiwów Państwowych, z 8 października 1969 r.

${ }^{125}$ Rutkowski, Żydowski Instytut Historyczny i jego pracownicy..., s. 41.

${ }^{126}$ Podając się do dymisji, Artur Eisenbach chciał zaprotestować przeciw kłamliwym oskarżeniom kierowanym pod adresem ŻIH przez organy partyjno-rządowe oraz próbie „rozczłonkowania” placówki (głównie poprzez przekazanie wszystkich materiałów dotyczących okupacji hitlerowskiej GKBZH, a zasobów muzealnych i bibliotecznych - wybranym instytucjom). Swoje ustąpienie motywował również niemożliwością obrony Instytutu i jego kolektywu.

${ }^{127}$ APAN, sygn. II-73 W.667/64. Żydowski Instytut Historyczny w Polsce (Zarys historii Instytutu i analiza jego stanu obecnego). Do końca 1968 r. wyemigrowało z Polski pięciu pracowników naukowo-badawczych: Danuta Dąbrowska, Adam Wein i Wila Orbach 
pochodzenia żydowskiego) zerwało kontakt z ŻIH, a coraz mniej liczni członkowie Stowarzyszenia przygotowywali się do wyjazdu.

Antyżydowska kampania Marca '68 doprowadziła również do tymczasowego sprawowania funkcji kierowniczej (p.o. dyrektora) przez Adama Rutkowskiego. Po jego ustapieniu ze stanowiska, na mocy uchwały z 30 września 1968 r., spośród członków Zarządu wyłoniono trzyosobowy zespół, który podjął się pełnienia stałych dyżurów w Instytucie. Zespół ten, w składzie: Salo Fiszgrund (p.o. przewodniczącego Zarządu), Józef Barski i Dawid Sfard, zobowiązał się również do przeprowadzenia rozmów z kandydatami na stanowisko dyrektora $\dot{Z} \mathrm{IH}^{128}$. Po ustąpieniu z dniem 10 października 1968 r. Adama Rutkowskiego ze stanowiska p.o. dyrektora i do czasu wyłonienia nowego dyrektora Zarząd (po przedłożeniu propozycji przez zespół na podstawie protokołu zdawczo-odbiorczego) upoważnił Tatianę Berenstein do prowadzenia prac naukowo-wydawniczych Instytutu, a Mariana Fuksa - prac organizacyjno-administracyjnych i finansowych ${ }^{129}$.

W efekcie pertraktacji i osiągnięcia porozumienia z Wydziałem I PAN stanowisko dyrektora ŻIH objął 10 stycznia 1969 r. Szymon Datner ${ }^{130}$. Na mocy uchwały Zarządu z 2 lipca 1969 r. - podjętej zgodnie ze statutem Stowarzyszenia ŻIH, który zakładał, że przewodniczący Zarządu jest jednocześnie dyrektorem Instytutu (rozdz. V, art. 25) - Datner został powołany na stanowisko przewodniczącego. Jego zastępcami zostali Edward Rajber (pełniący także funkcję przewodniczącego TSKŻ) i Janina Morgenstern (będąca etatowym pracownikiem Instytutu) ${ }^{131}$. Nowy przewodniczący

- z biblioteki ŻIH, Stefan Krakowski - kierownik archiwum, oraz Adam Rutkowski. W następnych roku wyjechała Tatiana Berenstein. Zob. Rutkowski, Żydowski Instytut Historyczny i jego pracownicy..., s. 42; Horn, Działalność naukowa Żydowskiego Instytutu Historycznego w Polsce w latach 1947-1996..., s. 46.

${ }_{128}$ ASŻIH. Protokół z posiedzenia Zarządu ŻIH z 30 września 1968 r.; APAN, sygn. II-73 W.555/XXIII. Protokół z kontroli przeprowadzonej w ŻIH przez doradcę ekonomicznego Zespołu Oświaty, Nauki i Kultury NIK od 8 sierpnia do 25 listopada 1967 r.; Protokół z rewizji przeprowadzonej w ŻIH przez inspektora PAN od 9 kwietnia do 14 maja $1970 \mathrm{r}$. Kierownictwo w ŻIH, jak wynikało z wypowiedzi p.o. sekretarza I Wydziału PAN, mogła sprawować osoba nieposiadająca tytułu naukowego.

${ }^{129}$ ASŻIH. Protokół z posiedzenia Zarządu ŻIH z 24 października 1968 r.; IPN BU 3058/206. Notatka w sprawie ŻIH sekretarza Wydziału I Nauk Społecznych PAN, Tadeusza Cieślaka, z 18 października 1968 r.

${ }^{130}$ APAN, sygn. II-73 W.555/XXIII. Protokół z rewizji przeprowadzonej w ŻIH przez inspektora PAN od 9 kwietnia do 14 maja 1970 r. Zarząd ŻIH wybrał Szymona Datnera na stanowisko dyrektora już 25 listopada 1968 r. O zatwierdzenie tej kandydatury wystąpił następnie do PAN. Zob. APAN, sygn. II-73 W.555/XXIII. Wyciąg z protokołu posiedzenia Zarządu ŻIH, odbytego 25 listopada 1968 r.

${ }_{131}$ ASŻIH. Protokół z kontroli przeprowadzonej w ŻIH przez inspektora PAN od 2 do 15 grudnia $1971 \mathrm{r}$. 
wyraził nadzieję, że „mimo piętrzących się trudności, zwłaszcza kadrowych”, pracę Instytutu „uda się ustabilizować”132. Zaprezentował zarazem nieugiętą postawę w obronie prowadzonej przez siebie instytucji:

odtwarzamy w ŻIH mozolnie przeszłość naszą [żydowską - przyp. A.R.] w Polsce, przeszłość będącą cząstką Polski w ogóle. W czyim interesie jest zamazać i wymazać tę przeszłość i ten potężny wkład w historię i kulturę, gospodarkę i potęgę Polski? Pozycję tę będziemy trzymać i utrzymywać tak długo, jak będzie można. Będziemy ją trzymać za wszelką cenę $e^{133}$.

Trudną sytuację ŻIH, w jakiej znalazł się on pod wpływem sterowanej odgórnie nagonki antysemickiej, pogłębiały - pozostające nie bez związku z tą atmosferą - „określone układy osobowe” w jego zespole ${ }^{134}$. Na tle toczących się dyskusji nad zmianą statutu działacze skupieni wokół jednego z członków Zarządu, Józefa Barskiego, przedstawiali postulat rozgraniczenia funkcji prezesa i Zarządu od dyrektora ŻIH, który byłby uzależniony w swoim działaniu od Zarządu, a członkiem tego organu stałby się tylko w wyniku wyboru. Szymon Datner z kolei optował za odpowiadającym statutowym zapisom rozwiązaniem, łączącym w jednej osobie stanowiska prezesa Stowarzyszenia i dyrektora Instytutu. Próbę kwestionowania prawnego porządku interpretował jako - motywowane osobistymi ambicjami - dążenia Barskiego do objęcia funkcji prezesa Stowarzyszenia i zarazem obniżenia pozycji dyrektora, sprowadzanego przy takim rozwiązaniu do roli „wykonawcy” poleceń Zarządu. Rozbieżności pomiędzy niektórymi członkami Zarządu i dyrektorem w kwestii określenia obowiązków i odpowiedzialności poszczególnych organów Stowarzyszenia były w opinii Datnera wyrazem pozornej na zewnątrz solidarności zespołu ŻIH.

Jeszcze w połowie 1969 r. USW PRN m.st. Warszawy, kontynuując walkę z ostatnimi instytucjami życia zbiorowego Żydów oraz wykorzystując różnice stanowisk wśród władz ŻIH w sprawie modelu zarządzania nim, nie widział „perspektyw rozwojowych dla Instytutu jako państwowej placówki

132 ASŻIH. Protokół z posiedzenia Zarządu ŻIH z 2 lipca 1969 r.

${ }^{133}$ IPN BU 1585/7362. Sprawozdanie dyrektora ŻIH, Szymona Datnera, na Walnym Zebraniu członków Stowarzyszenia odbytym 7 czerwca 1969 r.

${ }_{134}$ IPN BU 1585/7395. Informacja o działalności Stowarzyszenia ŻIH, z 16 czerwca 1969 r., przekazana przez zastępcę kierownika USW PRN m.st. Warszawy dyrektorowi Departamentu Społeczno-Administracyjnego MSW; Notatka służbowa z rozmowy przeprowadzonej 29 kwietnia 1969 r. z dyrektorem ŻIH, Szymonem Datnerem, w USW Rady Narodowej m.st. Warszawy. 
naukowej, jak również jako Stowarzyszenia”"135. Sugerował „włączenie ŻIH do TSKŻ na zasadzie jednostki organizacyjnej o specjalistycznym charakterze, nadzorowanej i ewentualnie dotowanej [...] przez PAN" (ale nieposiadającej osobowości prawnej), a „w perspektywie najwyżej 2 lat - doprowadzenie do zwołania Nadzwyczajnego Walnego Zebrania ŻIH i TSKŻ w celu podjęcia uchwały o połączeniu się"136. Absurdalne pomysły kierownictwa USW PRN m.st. Warszawy, oparte na zanegowaniu ponaddwudziestoletniego dorobku ŻIH, nie doczekały się żadnego znaczącego oddźwięku, choć jeszcze w 1972 r. - i to w samym środowisku żydowskim - do nich powrócono ${ }^{137}$.

Podsumowując działalność Instytutu za pierwsze półrocze 1970 r., jego dyrektor zaliczył do osiągnięć m.in. regularne wydawanie „Biuletynu ŻIH” przy małym zespole redakcyjnym (początkowo trzy-, a później dwuosobowym $)^{138}$, uzupełnienie stanu etatowego pracowników naukowych oraz „owocne” prace porządkowe w bibliotece i archiwum. „Do minusów w pracy Instytutu" należały -zdaniem dyrektora - nieuregulowanie sprawy zorganizowania Muzeum oraz nieukazywanie się „Bleter far Geszichte”139 (kolejny tom oddany zostanie do druku dopiero w 1977 r., natomiast ukaże się trzy lata później ${ }^{140}$ ). Zdaniem Datnera, „Instytut powinien [...] trwać i ma rację bytu, jako ważny czynnik stabilizujący życie społeczności żydowskiej w Polsce" ${ }^{141}$. Poprawę atmosfery w ŻIH przyniosło zgłoszenie kandydatur na członków Rady Naukowej i jej ukonstytuowanie się.

135 Zob. przyp. 90.

${ }^{136}$ Tamże. Pomysł połączenia ŻIH i TSKŻ zaczerpnięto m.in. z doświadczeń obu stowarzyszeń w organizowaniu wspólnych przedsięwzięć (np. wystaw). IPN BU 1585/7394. Pismo zastępcy dyrektora Departamentu Społeczno-Administracyjnego MSW do Wiceministra Spraw Wewnętrznych z 16 sierpnia 1969 r.

${ }_{137}$ Dosyć niespodziewaną koncepcję zlikwidowania samodzielnego bytu ŻIH w wyniku połączenia go z TSKŻ (na zasadzie swoistej unii personalnej) sformułowano w czerwcu 1972 r. na łamach, wydawanego przez Towarzystwo, pisma „Fołks-Sztyme”. IPN BU 1585/7394. Notatka z wizyty zastępcy przewodniczącego Zarządu ŻIH, Józefa Barskiego, w Wydziale I Departamentu Społeczno-Administracyjnego MSW, odbytej 19 czerwca $1972 \mathrm{r}$.

${ }^{138}$ ASŻIH. Protokół z posiedzenia Zarządu ŻIH 3 lipca 1970 r. W kategorii „ujemnego zjawiska” traktowano brak recenzji „Biuletynu”.

${ }_{139}$ Tamże. W sprawie powołania Muzeum (rozpatrywano możliwość utworzenia placówki o nazwie „Muzeum Sztuki i Zabytków Kultury Żydowskiej”) Szymon Datner zwracał się trzykrotnie do MKiS, jednak ze strony resortu nie uzyskał odpowiedzi.

${ }^{140}$ Horn, Działalność Żydowskiego Instytutu Historycznego w Polsce w latach 1967$1979 \ldots$... s. 15; APAN, sygn. II-73 W.667/64. Sprawozdanie z działalności ŻIH za 1977 r.; Protokół nr 151 posiedzenia Zarządu ŻIH z 30 marca 1976 r.; Protokół nr 150 posiedzenia Zarządu ŻIH z 24 lutego 1976 r.

${ }^{141}$ ASŻIH. Protokół z posiedzenia Zarządu ŻIH 3 lipca 1970 r. 
Szymon Datner faktycznie przewodził ŻIH do 27 lipca 1970 r. ${ }^{142}$ Podobnie jak w okresie poprzedzającym objęcie przez niego stanowiska przewodniczącego Zarządu Stowarzyszenia (od 10 stycznia do 1 lipca 1969 r. sprawował tylko funkcję dyrektora Instytutu) także po jego ustąpieniu funkcje przewodniczącego i dyrektora zostały rozdzielone. Niemal rok później, na mocy uchwały Zarządu z 6 maja 1971 r., postanowiono sprzecznie z zapisami statutu - „utrzymać dotychczasową praktykę rozdziału wyżej wymienionych funkcji” ${ }^{143}$ (prezes Zarządu sprawował „ogólny nadzór nad działalnością ŻIH”, natomiast dyrektor stał „,na czele aparatu wykonawczego Instytutu, zatrudnionego zarówno w komórkach naukowych i wydawniczych, jak i administracyjno-gospodarczych") ${ }^{144}$.

Po Datnerze przewodniczącym Zarządu został Edward Rajber ${ }^{145}$, natomiast funkcję dyrektora Instytutu przejął Marian Fuks, który do czasu formalnego powołania na to stanowisko (6 maja 1971 r.) piastował je z upoważnienia Zarządu ŻIH ${ }^{146}$. Rajber utrzymał się na stanowisku do 1981 r., natomiast Fuks stał na czele Instytutu do końca lutego 1973 r. ${ }^{147}$ Rozdział funkcji przewodniczącego Zarządu i dyrektora Instytutu utrzymał się do 1976 r., tj. do daty uchwalenia nowego statutu, w którym kwestię układu zależności między tymi stanowiskami poddano ponownej regulacji.

W celu zaktywizowania wylęknionej w dużym stopniu, zrezygnowanej i niepewnej swojego losu w Polsce społeczności żydowskiej oraz z potrzeby

142 Tamże. Rezygnację ze stanowiska dyrektora Szymon Datner złożył 30 maja 1970 r. w piśmie skierowanym do członków Zarządu ŻIH (choć anonsował ją już na posiedzeniu Zarządu 9 marca 1970 r.), zachowując w ten sposób trzymiesięczny okres wypowiedzenia. APAN, sygn. II-73 W.555/XXIII. Protokół z posiedzenia Zarządu ŻIH z 27 lipca 1970 r.; Protokół z posiedzenia Zarządu ŻIH z 9 marca 1970 r.; IPN BU 1585/7370. Rezygnacja Szymona Datnera ze stanowiska dyrektora ŻIH złożona 30 maja 1970 r. wiceprzewodniczącemu Zarządu, Edwardowi Rajberowi.

${ }^{143}$ IPN BU 1585/7395. Protokół z kontroli przeprowadzonej w ŻIH od 13 lutego do 15 marca 1973 r. przez USW PRN m.st. Warszawy.

${ }^{144}$ IPN BU 1585/7360. Odpis regulaminu działalności Zarządu i dyrektora ŻIH uchwalonego na posiedzeniu Zarządu 6 maja $1971 \mathrm{r}$.

${ }^{145}$ Edward Rajber pełnił początkowo funkcję p.o. przewodniczącego. APAN, sygn. II73 W.555/XXIII. Protokół z kontroli przeprowadzonej w ŻIH przez inspektora PAN od 2 do 15 grudnia 1971 r.; Protokół z kontroli przeprowadzonej w ŻIH przez inspektora PAN od 15 lutego do 24 marca 1973 r.

146 Tamże. Ze sprawozdania Zarządu ŻIH z działalności Instytutu od 7 czerwca 1969 r. do 15 lutego 1972 r. wynika, że Fuks objął formalnie stanowisko dyrektora 1 sierpnia 1971 r. IPN BU 1585/7388.

147 APAN, sygn. II-73 W.555/XXIII. Protokół z Walnego Zebrania Towarzystwa Naukowego ŻIH odbytego 27 marca 1974 r.; Protokół z kontroli przeprowadzonej w ŻIH przez inspektora PAN od 15 lutego do 24 marca 1973 r. 
znalezienia wsparcia dla zagrożonego zakusami organów państwowych bytu Instytutu Stowarzyszenie przy współudziale TSKŻ podjęło w $1969 \mathrm{r}$. próbę utworzenia Kół Przyjaciół ŻIH w większych skupiskach żydowskich $^{148}$. Z powodu jednak utrzymujących się nastrojów antysemickich i emigracyjnych plany te nie doczekały się realizacji.

W listopadzie 1967 r., a zatem w „przeddzień” tzw. wydarzeń marcowych, Stowarzyszenie ŻIH liczyło 81 członków $^{149}$. Instytut zatrudniał wówczas - poza dyrektorem Eisenbachem, który jako pracownik nieetatowy nie pobierał żadnego uposażenia - 9 pełnoetatowych pracowników nauki ${ }^{150}$. Do listopada 1970 r. w Stowarzyszeniu pozostało 45 członków, natomiast pracę na etatach naukowych podejmowało 7 osób ${ }^{151}$ (rok wcześniej- 8 osób) $)^{152}$. W kolejnym roku liczba członków Stowarzyszenia zwiększyła się do $190^{153}$, natomiast liczba pracowników naukowych w Instytucie pozostała bez zmian ${ }^{154}$.

${ }^{148}$ IPN BU 1585/7395. Protokół z kontroli przeprowadzonej w Stowarzyszeniu ŻIH przez pracowników USW PRN m.st. Warszawy, na podstawie delegacji służbowej z 14 stycznia 1969 r. Postulat powołania takich kół członkowie Stowarzyszenia wysuwali już w 1963 r.

149 AAN, NIK 42/101. Informacja o wynikach kontroli przeprowadzonej w ŻIH przez NIK w IV kwartale $1967 \mathrm{r}$.

${ }^{150}$ AAN, NIK 42/101. Protokół z kontroli przeprowadzonej w ŻIH przez doradcę ekonomicznego z Zespołu Oświaty, Nauki i Kultury NIK od 8 sierpnia do 25 listopada 1967 r. Z osób pracujących w ŻIH tylko prof. Bernarda Marka i dyrektora Artura Einsenbacha PAN zakwalifikowała do pracowników nauki. Zob. AAN, NIK 42/101. Informacja o wynikach kontroli przeprowadzonej w ŻIH przez NIK w IV kwartale $1967 \mathrm{r}$.

${ }^{151}$ APAN, sygn. II-73 W.555/XXIII. Notatka służbowa w związku z protokołem NIK, sporządzona 1 grudnia 1970 r. przez dyrektora ŻIH, Mariana Fuksa, i wiceprzewodniczącego Zarządu ŻIH, Józefa Barskiego.

${ }^{152}$ IPN BU 1585/7368. Odpis pisma dyrektora ŻIH, Szymona Datnera, do USW Stołecznej RN w Warszawie, z 23 grudnia $1969 \mathrm{r}$.

${ }^{153}$ IPN BU 1585/7395. Notatka służbowa o ŻIH z 11 marca 1972 r. przesłana naczelnikowi Wydziału I Departamentu Społeczno-Administracyjnego MSW przez USW PRN m.st. Warszawy. Podczas kontroli zewnętrznych w Instytucie jego Zarządowi zarzucano sztuczne zawyżanie stanu liczbowego członków, m.in. poprzez przyjmowanie osób, które nie mają odpowiedniego, wymaganego charakterem działalności Stowarzyszenia, wykształcenia, wyemigrowały z Polski lub zmarły - zob. IPN BU 1585/7395. Protokół z kontroli przeprowadzonej w ŻIH od 13 lutego do15 marca 1973 r. przez USW PRN m.st. Warszawy.

${ }^{154}$ W 1971 r. niektóre organy państwowe kontrolujące ŻIH sprowadzały liczbę pracowników naukowych w nim zatrudnionych do pięciu. ASŻIH. Protokół kontroli przeprowadzonej w ŻIH przez inspektora PAN od 2 do 15 grudnia 1971 r.; APAN, sygn. II-73 W.555/ XXIII. Protokół z kontroli przeprowadzonej w ŻIH przez inspektora PAN od 15 lutego do 24 marca $1973 \mathrm{r}$. 


\section{Starania Żydowskiego Instytutu Historycznego o unormowanie sytuacji prawnej jego siedziby}

Po wojnie gmach dawnej Głównej Biblioteki Judaistycznej na mocy przepisów Dekretu z dnia 26 października 1945 r. o własności i użytkowaniu gruntów na obszarze m.st. Warszawy ${ }^{155}$ został przejęty na rzecz Skarbu Państwa (do księgi wieczystej na wniosek Wydziału Gospodarki Terenami PRN m.st. Warszawy wpisany został dopiero w 1960 r.) ${ }^{156}$. Spalony przez hitlerowców obiekt (o powierzchni użytkowej $2500 \mathrm{~m}^{2}$ ) władze państwowe przekazały jednak społeczności żydowskiej. Centralny Komitet Żydów w Polsce odbudował go w 1947 r. z funduszy Joint (kosztem 9 mln zf) i przydzielił CŻKH, przekształconej już w tym czasie w ŻIH ${ }^{157}$. Do $1950 \mathrm{r}$. - daty rozwiązania CKŻP - ,wszelkie obowiązki faktyczne wypływające ze stanu administrowania gmachem były [...] wykonywane" przez Komitet ${ }^{158}$. Choć sytuacja prawna budynku nie była formalnie uregulowana ${ }^{159}$, to praw Instytutu do wykorzystywania go na swoją siedzibę nikt nie kwestionował (placówkę zwolniono też od wszelkich opłat czynszowych ${ }^{160}$ ).

Od 12 lutego 1960 r. gmach zajmowany przez ŻIH, w którym siedziby miały także Instytut Historii Kultury Materialnej (IHKM) i Instytut Geografii PAN, stał się na podstawie wpisu do księgi wieczystej własnością Skarbu Państwa ${ }^{161}$. Umowę pomiędzy ŻIH a IHKM o wynajmie pomieszczeń zawarto 2 stycznia 1964 r. ${ }^{162}$ Najemcą obiektu z ramienia PAN - ponoszącej w głównej mierze ciężar finansowania Stowarzyszenia - został IHKM, ŻIH natomiast był wynajmującym. W celu uporządkowania stanu prawnego obiektu Zarząd Stowarzyszenia wystąił 8 października 1968 r. do Wydziału

155 Dz.U. P.P. z 1945 r. Nr 50, poz. 279.

${ }^{156}$ IPN BU 1585/7372. Notatka zastępcy naczelnika Wydziału z 20 listopada 1970 r.

${ }^{157}$ Instytut nie był jedynym użytkownikiem budynku, na przykład w 1951 r. „prawie połowę gmachu” zajmowały również drukarnia, zecernia i administracja gazety „Dos Naje Lebn” („Nowe Życie”). Zob. AŻIH, AO. Odpowiedź dyrektora ŻIH, Bernarda Marka, udzielona 9 marca 1951 r. ZG TSKŻ w sprawie obowiązków administracyjnych i porządkowych w siedzibie Instytutu.

158 Tamże.

${ }^{159}$ Brak regulacji prawnej obiektu ujawniał się zazwyczaj, przysparzając trudności ŻIH, w perspektywie konieczności przeprowadzenia jego remontu. Poniesienie kosztów z nim związanych w $1951 \mathrm{r}$. było według władz Instytutu obowiązkiem TSKŻ - ,instytucji, która przejęła agendy po CKŻP”. Tamże.

${ }_{160}$ AŻIH, AO. Odpowiedź sekretarza generalnego TSKŻ, Juliana Łazebnika, na pismo dyrekcji ŻIH, z 15 maja 1951 r., w sprawie funduszy na remont siedziby Instytutu.

161 AAN, NIK 42/101. Notatka służbowa starszego inspektora kontroli państwowej Zespołu Budżetu Państwa i Finansów NIK z 25 kwietnia 1969 r.

162 Tamże. 
Gospodarki Komunalnej PRN m.st. Warszawy z wnioskiem o przekazanie ŻIH nieruchomości w użytkowanie wieczyste ${ }^{163}$. Wydział, bez powiadamiania Instytutu o efektach złożonego przezeń wniosku, przekazał jednak obiekt $\mathrm{PAN}^{164}$. Akademia stała się użytkownikiem gruntu i budynku, stanowiących własność Skarbu Państwa, na podstawie decyzji Wydziału Gospodarki Komunalnej i Mieszkaniowej PRN m.st. Warszawy z 10 lipca 1969 r. Decyzja ta była konsekwencją sfinansowania w 1964 r. przez PAN (ze środków przydzielonych IHKM) remontu kapitalnego centralnego ogrzewania w budynku, o którego przeprowadzenie ze środków Akademii starał się od stycznia tego roku Instytut. Prokuratura wojewódzka w Warszawie zakwestionowała zasadność przeprowadzonych prac, ponieważ obiekt nie stanowił własności PAN. Ulegając sugestii prokuratury, Akademia wystąpiła 7 maja 1969 r. - po upływie ponad pół roku od złożenia wniosku przez Instytut - do Prezydium Stołecznej Rady Narodowej o przydział tego gmachu w użytkowanie i administrację. Wspomnianą decyzją Prezydium z 10 lipca 1969 r. PAN nieruchomość tę otrzymała ${ }^{165}$. Instytut odwołał się jednak 30 lipca tegoż roku od tej decyzji („,mając przede wszystkim na uwadze polityczny wydźwięk, jaki może wywołać w obecnym okresie pozbawienie społeczności żydowskiej tej jego niewątpliwie najcenniejszej placówki”), co skłoniło Wydział I Akademii do wysłania 5 sierpnia 1969 r. pisma do ŻIH z poparciem dla jego starań ${ }^{166}$. Jednak już po upływie miesiąca ( 8 września) z tegoż Wydziału napłynęła informacja diametralnie odmienna, cofająca udzielone Instytutowi popar$\mathrm{cie}^{167}$. Na wieść o piśmie skierowanym przez ŻIH do Ministerstwa Gospodarki Komunalnej 24 września 1969 r. z prośbą o uchylenie niekorzystnej

163 IPN BU 1585/7372. Pismo Ministerstwa Gospodarki Komunalnej do Departamentu Społeczno-Administracyjnego MSW, z 26 czerwca 1970 r., z prośbą o zajęcie stanowiska w sprawie formy użytkowania przez ŻIH obiektu przy al. gen. Świerczewskiego 79.

${ }_{164}$ APAN, sygn. II-73 W.667/66. Memoriał ŻIH skierowany 2 sierpnia 1973 r. do Prezesa PAN w sprawie uchylenia decyzji o przekazaniu budynku Instytutu w administrację Instytutu Badań Literackich PAN.

${ }_{165}$ AAN, NIK 42/101. Pismo dyrektora Zespołu Budżetu Państwa i Finansów NIK do Prokuratury Wojewódzkiej dla m.st. Warszawy, z 2 maja 1969 r.; Notatka służbowa st. inspektora kontroli państwowej Zespołu Budżetu Państwa i Finansów NIK, z 25 kwietnia 1969 r. Zob. także APAN, sygn. II-73 W.555/XXIII. Notatka dla Sekretarza Naukowego PAN w sprawie ŻIH, z 11 grudnia 1969 r.; tamże, sygn. II-73 W.667/66. Opinia o sytuacji prawnej budynku zajmowanego przez ŻIH, przekazana przez zastępcę sekretarza Wydziału I PAN do dyrektora generalnego PAN 16 sierpnia 1973 r.; Pismo Sekretarza Naukowego PAN do Prezydenta m.st. Warszawy w sprawie budynku przy al. Świerczewskiego 79, z 14 lutego $1975 \mathrm{r}$.

166 APAN, sygn. II-73 W.667/66. Pismo przewodniczącego Zarządu i dyrektora ŻIH, Szymona Datnera, do Ministra Gospodarki Komunalnej z 24 września 1969 r.

167 Tamże. 
decyzji w sprawie posesji i terenu przy al. gen. Świerczewskiego 79 (obecnie ul. Tłomackie 5) Akademia 12 grudnia 1969 r. złożyła zawiadomienie do PRN m.st. Warszawy o rezygnacji z przyznanych jej uprawnień do budynku na korzyść Instytutu (wskazując na „racje historyczne i kulturowe” stojące za takim przekazaniem). Mimo przychylnego wnioskowi ŻIH stanowiska PAN Ministerstwo Gospodarki Komunalnej postanowieniem z 26 września 1969 r. utrzymało w mocy zaskarżoną decyzję ${ }^{168}$. Z ponownym - i tak samo nieskutecznym - wnioskiem wyrażającym poparcie dla starań ŻIH o przekazanie mu budynku w użytkowanie wieczyste Akademia wystąpiła jeszcze 12 lipca 1972 r. ${ }^{169}$

Unormowanie sytuacji na korzyść Instytutu nastąpiło pięć lat później. Na podstawie porozumienia zawartego 30 kwietnia 1977 r. pomiędzy dyrektorem generalnym PAN a dyrektorem ŻIH Akademia, będąc użytkownikiem zabudowanej nieruchomości przy al. gen. Świerczewskiego 79, przekazała wymienioną nieruchomość ŻIH w używanie na cele związane $\mathrm{z}$ jego statutową działalnością. Umowa, z mocą obowiązującą od 1 maja tego roku, została zawarta na „czas nieoznaczony” ${ }^{170}$.

\section{9. „Specjalistyczne” towarzystwo naukowe}

Niezgodne z obowiązującym statutem rozejście się funkcji przewodniczącego Zarządu i dyrektora Instytutu wymagało wprowadzenia korekt w jednej ze sfer: praktycznej lub prawnej. Dostosowanie litery prawa do stanu faktycznego nastąpiło w wyniku zatwierdzenia 15 lipca $1976 \mathrm{r}$. nowego statutu $^{171}$, który nie ustanawiał połączenia funkcji przewodniczącego

168 APAN, sygn. II-73 W.667/66. Memoriał ŻIH skierowany 2 sierpnia 1973 r. do Prezesa PAN w sprawie uchylenia decyzji o przekazaniu budynku Instytutu w administrację Instytutu Badań Literackich PAN.

169 Tamże. Rok później (pismem z 11 lipca 1973 r.) Biuro Inwestycyjno-Gospodarcze PAN przystąpiło do próby przekazania budynku Instytutowi Badań Literackich PAN. Na skutek interwencji ŻIH nie została ona zrealizowana. APAN, sygn. II-73 W.555/XXIII. Protokół z posiedzenia Zarządu ŻIH z 24 lipca 1973 r.

170 APAN, sygn. II-73 W.667/66. Porozumienie zawarte 30 kwietnia 1977 r. pomiędzy dyrektorem generalnym PAN a dyrektorem ŻIH w sprawie przekazania w używanie i administrowanie nieruchomości położonej przy al. gen. Świerczewskiego 79 w Warszawie; Umowa powiernicza Nr 11/79 pomiędzy ŻIH a Zarządem Inwestycji PAN przesłana do Akademii 12 czerwca 1979 r.

${ }^{171}$ IPN BU 1585/7360. Decyzja Wydziału Spraw Wewnętrznych Urzędu m.st. Warszawy z 15 lipca 1976 r. o zatwierdzeniu zmian statutu Stowarzyszenia pod nazwą „Żydowski Instytut Historyczny”. Do statutu z 3 kwietnia 1964 r. zgłoszono poprawki, przyjęte na Nadzwyczajnym Walnym Zgromadzeniu Instytutu 19 grudnia 1975 r. Zob. APAN, sygn. 
Zarządu ze stanowiskiem dyrektora $\dot{Z} I H^{172}$. W nowym statucie, uwzględniającym w dużym stopniu propozycje zmian sugerowane przez MSW, nie określono zakresu kompetencji i uprawnień dyrektora Instytutu. Kierował on wprawdzie bieżącą pracą podległej sobie placówki, ale statut ŻIH nie upoważniał go do podejmowania decyzji i działań obejmujących uprawnienia organów statutowych ŻIH ${ }^{173}$. Do zatwierdzenia regulaminów i instrukcji wewnętrznych, opracowanych przez dyrektora, upoważniony był jedynie Zarząd. Dyrektor sprawował więc funkcję o charakterze wykonawczym. Ramy statutowe, umiejscawiające dyrektora wyłącznie w wewnętrznej strukturze organizacyjnej Stowarzyszenia, nie wyposażyły go w uprawnienia porównywalne do tych, które posiadali dyrektorzy innych instytutów naukowo-badawczych.

Warto dopowiedzieć, że w myśl nowego statutu władzami Stowarzyszenia były: Walne Zebranie, Zarząd i Komisja Rewizyjna (par. 15). Zarząd posiadał uprawnienia do ,reprezentowania instytutu [Stowarzyszenia - przyp. A.R.] na zewnątrz" (par. 24). Żadne z postanowień statutu nie wyodrębniało ze Stowarzyszenia ŻIH instytutu naukowo-badawczego ${ }^{174}$. O takowym nie mogło stanowić również - z powodów omówionych - istnienie stanowiska dyrektora Instytutu ${ }^{175}$.

Żydowski Instytut Historyczny należał do „specjalistycznych” towarzystw naukowych dotowanych przez PAN, objętych bezpośrednią opieką jej Wydziału I (Nauki Społeczne) $)^{176}$. Zgodnie z ówczesnym stanem prawnym, zwłaszcza z uchwałą Rady Państwa z 12 maja 1979 r. (o umocnieniu roli społecznego ruchu naukowego), towarzystwa te posiadały pewien

II-73 W.667/64. Protokół z przebiegu Nadzwyczajnego Walnego Zgromadzenia członków Stowarzyszenia ŻIH, odbytego 19 grudnia 1975 r.; Odpowiedź dyrektora ŻIH, Maurycego Horna, z 19 lutego 1976 r., na list zastępcy sekretarza Wydziału I PAN w sprawie działalności Stowarzyszenia w latach 1976-1980.

172 ASŻIH. Wyjaśnienia p.o. dyrektora ŻIH, Maurycego Horna, dotyczące protokołu kontroli działalności ŻIH w latach 1984-1986, przeprowadzonej przez Biuro Kontroli PAN od lipca do września 1987 r.

${ }^{173}$ IPN BU 1585/7360. Statut Stowarzyszenia pod nazwą „Żydowski Instytut Historyczny w Polsce".

174 Żydowski Instytut Historyczny był placówką naukowo-badawczą działającą pod opieką PAN i dla realizacji statutowego celu Stowarzyszenia (par. 3). Były to więc działania realizowane bezpośrednio przez Stowarzyszenie.

175 ASŻIH. Protokół kontroli przeprowadzonej w ŻIH, od 13 lipca do 18 września 1987 r., przez specjalistę Biura Kontroli PAN.

176 Oprócz ŻIH do Towarzystw Naukowych specjalistycznych należały m.in. Polskie Towarzystwo Orientalistyczne, Polskie Towarzystwo Archeologiczno-Numizmatyczne, Polskie Towarzystwo Demograficzne, Polskie Towarzystwo Pedagogiczne, Instytut Zachodni, Polskie Towarzystwo Historyczne. 
- warunkowany ówczesnym systemem politycznym - zakres autonomii wewnętrznej ${ }^{177}$. Akademia sprawowała nad nimi opiekę merytoryczną i udzielała odpowiedniej pomocy materialnej. Przynależność do towarzystw podlegających nadzorowi PAN (zwłaszcza tych mających charakter specjalny, tj. związanych ściśle z instytutami naukowymi) świadczyła o uznaniu roli ŻIH (obok szkół wyższych i samej Akademii) w rozwoju nauk humanistycznych i społecznych.

Równolegle z pracami nad nowym statutem Stowarzyszenia ponownie podjęto intensywne starania w celu przekształcenia Biblioteki ŻIH w Centralną Bibliotekę Judaistyczną, a wystaw w Instytucie - w nowocześnie urządzoną placówkę muzealną. Celem orędowników tej idei było nadanie Muzeum uprawnień jednostki działającej na podstawie statutu zatwierdzonego przez MKiS i podlegającej ŻIH jako Stowarzyszeniu.

W grudniu 1975 r. w Instytucie zatrudnionych było dziewięciu pracowników naukowych ${ }^{178}$, na początku 1977 r. - ośmiu ${ }^{179}$, a w 1978 r. - dziesięciu ${ }^{180}$.

\section{Władze Żydowskiego Instytutu Historycznego po rozdzieleniu stanowisk przewodniczącego i dyrektora}

Statut przyjęty w 1976 r. nie wyodrębnił ze Stowarzyszenia ŻIH instytutu naukowo-badawczego, mimo to funkcje przewodniczącego Zarządu i dyrektora Instytutu uległy rozdzieleniu. Warto odnotować, że w analizowanym okresie następcą Mariana Fuksa na stanowisku dyrektora ŻIH został, 1 marca 1973 r., Maurycy Horn ${ }^{181}$. Po raz kolejny na to stanowisko, tym razem na trzy lata, został wybrany 14 września 1982 r. Jednocześnie udzielono mu bezpłatnego urlopu naukowego od 1 października $1982 \mathrm{r}$. do 30 września 1983 r. ${ }^{182}$ Pod nieobecność urlopowanego Horna pełnienie

177 APAN, sygn. II-73 W.667/64. Ocena działalności i finansowania Towarzystw Naukowych znajdujących się pod nadzorem Wydziału I PAN (1987 r.).

178 APAN, sygn. II-73 W.667/64. Załącznik do protokołu z przebiegu Nadzwyczajnego Walnego Zebrania członków Stowarzyszenia ŻIH, odbytego 19 grudnia 1975 r.

179 APAN, sygn. II-73 W.667/64. Sprawozdanie z działalności ŻIH za 1977 r.

${ }^{180}$ IPN BU 1585/7388. Sprawozdanie z działalności ŻIH w 1978 r.

181 APAN, sygn. II-73 W.667/64. ŻIH w Polsce - dokumentacja archiwalna (1975-1978; 1988 r.). Żydowski Instytut Historyczny w Polsce (Zarys historii Instytutu i analiza jego stanu obecnego). Zob. też tamże, sygn. II-73 W.555/XXIII. Protokół z kontroli przeprowadzonej w ŻIH przez inspektora PAN od 15 lutego do 24 marca 1973 r.; Protokół z Walnego Zebrania Stowarzyszenia ŻIH obradującego 27 marca 1974 r.; Informacja Zarządu Stowarzyszenia ŻIH po Walnym Zebraniu członków odbytym 21 lutego 1972 r.

182 ASŻIH. Protokół z posiedzenia Zarządu ŻIH 14 września 1982 r. 
obowiązków dyrektora powierzono Zygmuntowi Hoffmanowi, który sprawował tę funkcję dłużej, tj. do 31 marca 1985 r. ${ }^{183}$ Następnie - od 1 kwietnia 1985 r. do 30 czerwca 1987 r. - Instytutem kierował Ilia Epsztejn ${ }^{184}$.

Zmiany zachodziły również na stanowisku przewodniczącego Zarządu Stowarzyszenia. Po Edwardzie Rajberze, od maja 1980 r. do 27 listopada 1985 r., sprawował je Józef Barski, a następnie Szymon Datner (do 14 listopada 1988 r.).

\section{Próba zmiany układu zależności między Stowarzyszeniem a Instytutem pod wpływem zewnętrznych uwarunkowań prawnych}

Do próby regulacji statusu prawnego ŻIH doszło w połowie lat osiemdziesiątych XX w. pod wpływem uwarunkowań natury zewnętrznej. Wprowadzenie Ustawy z dnia 25 lipca 1985 r. o jednostkach badawczo-rozwojowych oraz Rozporządzenia Rady Ministrów z dnia 18 sierpnia 1986 r. w sprawie nadzoru naukowego Polskiej Akademii Nauk nad instytutami naukowo-badawczymi prowadzonymi przez stowarzyszenia wymusiło na działaczach ŻIH zmianę dotychczasowego układu zależności między Stowarzyszeniem a Instytutem.

Efektem dążeń do wpasowania się w obowiązujące normy prawne było opracowanie projektu nowego statutu Stowarzyszenia pod nazwą „Żydowski Instytut Historyczny w Polsce”, który przez Zarząd tegoż uchwalony został 18 marca 1987 r. Przyjęto w nim, że „ŻIH jest stowarzyszeniem zarejestrowanym i posiada osobowość prawną" (par. 2) ${ }^{185}$. Zapis tak sformułowany potwierdzał ścisłą zależność pomiędzy Stowarzyszeniem i Instytutem. Pewnym novum, świadczącym o próbie uwzględnienia obowiązujących regulacji prawnych, było postanowienie, że „Organem ŻIH powołanym do realizacji głównych celów Stowarzyszenia jest wchodzący w jego skład instytut naukowo-badawczy" (par. 6) ${ }^{186}$. Było to posunięcie

${ }^{183}$ Zob. przyp. 172.

184 Tamże.

185 ASŻIH. Projekt statutu Stowarzyszenia pod nazwą „Żydowski Instytut Historyczny w Polsce”, uchwalony przez Zarząd ŻIH 18 marca 1987 r.

${ }^{186}$ Akceptacji nie uzyskała propozycja zgłoszona przez członka Komisji Statutowej ŻIH, Aleksandra Pekentregera, polegająca na wprowadzeniu do statutu zapisu, że: „Celem Stowarzyszenia ŻIH jest wspieranie i udzielanie wszelkiej pomocy prowadzonemu przez siebie Instytutowi”. ASŻIH. Uwagi prawne i merytoryczne do projektu statutu Stowarzyszenia ŻIH i Żydowskiego Instytutu Historycznego w Polsce, z 3 marca 1987 r. 
w stronę podkreślenia odrębności organizacyjnej Instytutu, choć z pewnością niewystarczające - o czym w dalszej części - z punktu widzenia wymogów ustawy z 1985 r. o jednostkach badawczo-rozwojowych oraz rozporządzenia z $1986 \mathrm{r}$. o instytutach naukowo-badawczych ${ }^{187}$. Instytut nadal bowiem traktowano jako część („wchodzący w [...] skład”) Stowarzyszenia i - co znamienne - choć „występujący pod tą samą nazwą co Stowarzyszenie” (tj. Żydowski Instytut Historyczny), był „nazywany w dalszej części statutu Instytutem”. „Skrócona nazwa ŻIH” zarezerwowana była natomiast wyłącznie dla Stowarzyszenia (par. 1) ${ }^{188}$.

Funkcjonowanie Instytutu w strukturze Stowarzyszenia akcentowały również inne zapisy statutu. Zakreślając kompetencje Walnego Zebrania (najwyższej władzy ŻIH), założono „rozpatrywanie i przyjmowanie sprawozdań z działalności Stowarzyszenia i jego Instytutu [...], przy przestrzeganiu przepisów dotyczących nadzoru Polskiej Akademii Nauk" (par. 19 lit. a). Z kolei w gestii Zarządu pozostawało m.in.: „,wytyczanie kierunków działalności Stowarzyszenia i Instytutu [...] oraz sprawowanie nadzoru nad całokształtem działalności Instytutu” (par. 24 lit. a); „rozpatrywanie i opiniowanie rocznych planów pracy i budżetów oraz sprawozdań z działalności Stowarzyszenia i jego Instytutu” (par. 24 lit. b); „opiniowanie i zatwierdzanie regulaminu i struktury organizacyjnej Instytutu" (par. 24 lit. c). Mimo potraktowania Instytutu jako jednostki organizacyjnej zapisy nie pozostawiały wątpliwości co do stopnia jego odrębności. Na to, że pozostawał on integralną częścią Stowarzyszenia, wskazywały inne fragmenty statutu, wedle których do kompetencji Zarządu należało: „występowanie do Sekretarza Wydziału I Polskiej Akademii Nauk z wnioskiem o powołanie lub odwołanie dyrektora Instytutu” (par. 24, lit. i), „opiniowanie kandydatur na funkcje zastępców dyrektora Instytutu [...] i kierowników działalności merytorycznej oraz występowanie z wnioskami o odwołanie osób pełniących te funkcje" (par. 24, lit. j) ${ }^{189}$. Dominacja Stowarzyszenia nad Instytutem uwidoczniła się także w często stosowanym zwrocie: „, jego instytutu".

Rolę Instytutu w strukturze organizacyjnej Stowarzyszenia podkreślał - poświęcony wyłącznie temu pierwszemu - rozdział V statutu. Zawarte

187 Warto nadmienić, że w statucie pochopnie przyjęto, iż Instytut działa (,pod nadzorem naukowym” PAN) „zgodnie z Rozporządzeniem Rady Ministrów z dnia 18.08.1986 r.” (par. 6 pkt 2).

${ }_{188}$ Zob. przyp. 185.

189 Tamże. 
w nim postanowienia dotyczyły m.in.: organów Instytutu ${ }^{190}$, tj. Dyrektora i Rady Naukowej (par. 30); kompetencji dyrektora polegających na ustalaniu planu pracy, polityki kadrowej, zarządzaniu mieniem i odpowiadaniu za wyniki działalności Instytutu (par. 31). Zakres uprawnień dyrektora odpowiadał stopniowi wyodrębnienia podlegającej mu placówki ze struktury prawno-organizacyjnej Stowarzyszenia. Dyrektor Instytutu był bowiem zobligowany uzgadniać „, Z Zarządem ŻIH kandydatury przedstawione w swoich wnioskach władzom Polskiej Akademii Nauk, a także kandydatury na stanowiska [...] zastępców dyrektora, głównego księgowego i kierowników innych komórek organizacyjnych Instytutu" (par. 31 lit. g, f). Strukturę organizacyjną Instytutu „odpowiadającą przedmiotowi i zakresowi jego działania" określał natomiast regulamin ustalony przez dyrektora i zatwierdzony przez Zarząd (par. 33) ${ }^{191}$.

Stowarzyszenie, w którego składzie pozostawał Instytut, było wciąż organizacją o charakterze społecznym, ponieważ do obowiązków jego członków należała „praca społeczna na rzecz ŻIH” (par. 11 lit. d), a pełnienie przez członków funkcji we władzach ŻIH było honorowe (par. 13) ${ }^{192}$.

W projekcie nowego statutu, podobnie jak w poprzednim (z 1976 r.), nie było mowy o tym, że przewodniczący Zarządu Stowarzyszenia pełni jednocześnie funkcję dyrektora Instytutu. Co więcej, możliwość łączenia obu stanowisk była wykluczona, ponieważ - w myśl par. 23 - „Zarząd wybiera ze swego grona 4 członków Prezydium w składzie: przewodniczący, wiceprzewodniczący, sekretarz i skarbnik. Piątym członkiem Prezydium jest, z tytułu swojego stanowiska, dyrektor Instytutu"193.

Konstatując, należy podkreślić, że projekt statutu przyjęty przez Zarząd Stowarzyszenia ŻIH zawierał wiele przepisów, które - mimo powołania instytutu naukowo-badawczego - utrwalały podporządkowanie Instytutu i jego dyrektora Zarządowi Stowarzyszenia. Potwierdzał istnienie „organicznej więzi" między obiema instytucjami. Nowy statut nie spełniał więc wymogów Ustawy z dnia 25 lipca 1985 r. o jednostkach badawczo-rozwojowych oraz Rozporządzenia Rady Ministrów z dnia 18 sierpnia 1986 r.

${ }^{190}$ Statut zawierał pewną niekonsekwencję w stosowaniu terminu „organ”. Na podstawie treści par. 6 mówiącego, że instytut naukowo-badawczy jest „organem ŻIH”, oraz par. 30, w myśl którego „Organami Instytutu są: Dyrektor i Rada Naukowa”, można było wyciągnąć wniosek, iż Dyrektor i Rada Naukowa są organami organu.

191 Zob. przyp. 185.

192 Tamże.

193 Tamże. 
w sprawie nadzoru naukowego Polskiej Akademii Nauk nad instytutami naukowo-badawczymi prowadzonymi przez stowarzyszenia.

Warto tu wyjaśnić, gdzie tkwiło źródło wadliwych rozwiązań. Otóż delegacja $\mathrm{z}$ art. 78 ust. 2 wspomnianej ustawy upoważniała Radę Ministrów wyłącznie do określenia zakresu stosowania jej przepisów „»przez jednostki badawczo rozwojowe « organizacji społecznych, a nie przez

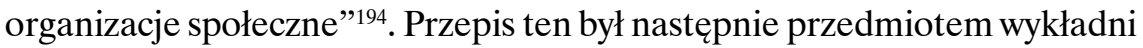
Biura Prawnego Urzędu Rady Ministrów ${ }^{195}$ wypowiedzianej w toku prac przygotowawczych do wydania wspomnianego rozporządzenia. Czytamy w niej, że:

Jeśli [...] Instytut naukowo-badawczy mimo takiej nazwy - nie jest odrębną jednostką, lecz tylko częścią stowarzyszenia, zastrzeżenia natury prawnej budziłoby projektowane rozciągnięcie na ten Instytut przepisów ustawy o jednostkach badawczo-rozwojowych, gdyż trudno byłoby w takim przypadku uznać za taką jednostkę część stowarzyszenia ${ }^{196}$.

Sprzeczna z wymienioną delegacją ustawową byłaby więc wykładnia rozporządzenia zakładająca, że w przypadku ŻIH przepisy tego rozporządzenia dotyczą części stowarzyszenia realizującej działalność naukowo-badawczą, gdyż stanowiłoby to ,jedno ze źródeł nieporozumień w praktyce"197. W świetle przepisów rozporządzenia (par. 1) sposobem na zniwelowanie sprzeczności mogłoby być użycie w odniesieniu do ŻIH zwrotu „prowadzonego przez stowarzyszenie pod nazwą", tak jak w przypadku instytutów wymienionych w tym przepisie (pkt 1 i 2 ). Będące wyrazem wspomnianej wykładni rozporządzenie, dla którego ustawa z 25 lipca 1985 r. stanowiła

194 Niemożność uznania za jednostkę badawczo-rozwojową części stowarzyszenia wynikała nie tylko z przepisów ustawy z 25 lipca 1985 r., ale i z ustawy wcześniej obowiązującej (z 17 lutego 1961 r.), która po wprowadzeniu nowej została uchylona. Warto nadmienić, że przepisy ustawy z $1961 \mathrm{r}$. odnosiły się do instytutów naukowo-badawczych, które organizacyjnie zostały wyodrębnione ze stowarzyszeń i w wyniku tego wyodrębniania przestały być częścią tych stowarzyszeń. Tak było m.in. w przypadku Instytutu Śląskiego w Opolu i Instytutu Zachodniego w Poznaniu, prowadzonych odpowiednio przez stowarzyszenia pod nazwami: „Instytut Śląski” w Opolu i „Instytut Zachodni w Poznaniu”. Instytuty te były wyraźnie wyodrębnione „spod struktury prawno-organizacyjnej” macierzystych stowarzyszeń mimo nieprzyznania im osobowości prawnej. O wyodrębnieniu instytutów decydowały: ich odrębny statut, odrębne organy statutowe (dyrektor, rada naukowa) oraz status dyrektora instytutu wyposażonego w prawo zarządzania całokształtem jego działalności i reprezentowania go na zewnątrz. ASŻIH. Protokół kontroli przeprowadzonej w ŻIH, od 13 lipca do 18 września 1987 r., przez specjalistę Biura Kontroli PAN.

195 Wykładnia ta wyrażona została w piśmie z 27 lutego 1987 r. do Sekretarza Naukowego PAN.

196 Zob. przyp. 175.

197 Tamże. 
podstawę prawną, odnosiło się więc do podmiotów, jakimi były instytuty naukowo-badawcze prowadzone przez stowarzyszenia, a nie prowadzące je stowarzyszenia (nadzór naukowy Sekretarza Naukowego PAN nad stowarzyszeniami regulowały inne przepisy).

Na potrzebę ponownego określenia relacji między Stowarzyszeniem a Instytutem wskazała pośrednio kontrola przeprowadzona w ŻIH, od 13 lipca do 18 września 1987 r., przez urzędnika Biura Kontroli PAN. Ustaliła ona, że w przypadku ŻIH prowadzonego przez „stowarzyszenie pod nazwą »Żydowski Instytut Historyczny w Polsce «” nie można „udowodnić istnienia" instytutu w rozumieniu rozporządzenia Rady Ministrów z 18 sierpnia 1986 r. Akt ten odnosił się bowiem ,do instytutów naukowo-badawczych istniejących prawnie jako wyodrębnione od macierzystych stowarzyszeń”, a ŻIH - mimo swej nazwy - nie był „odrębną jednostką organizacyjną, lecz tylko częścią stowarzyszenia”. Tak usytuowany Instytut nie mógł też być uznany za jednostkę badawczo-rozwojową w rozumieniu art. 78 ust. 2 ustawy z 25 lipca 1985 r., której zakres przepisów - jak wspomniano - stosowano do instytutów naukowo-badawczych ${ }^{198}$. W protokole kontrolnym stwierdzono, że „»mimo takiej nazwy« ŻIH w Polsce jest wyłącznie stowarzyszeniem, z którego organizacyjnie nie został wyodrębniony instytut naukowo-badawczy o tej samej nazwie" 199 . Ustalano ponadto, że według statutu określenie „Instytut” jest skrótem nazwy „Stowarzyszenia”, a więc „ilekroć w treści statutu mówi się o »instytucie «, to można i należy przez to określenie rozumieć tylko stowarzyszenie"200.

\section{Debata wokół projektu nowego statutu}

Zatwierdzenie projektu statutu poprzedziła pełna emocji dyskusja wśród członków ŻIH. Do projektu przyjętego przez Zarząd zgłoszono bowiem liczne zastrzeżenia i poprawki, składające się na tzw. kolektywny projekt opracowany przez ówczesnego dyrektora Instytutu, Ilię Epsztejna, oraz grupę popierających go pracowników. Osią sporu był projektowany układ zależności między Stowarzyszeniem a Instytutem oraz zakres kompetencji przypisywanych dyrektorowi Instytutu. Epsztejn krytycznie odnosił się m.in. do postanowienia zawartego w ,konkurencyjnym” projekcie, według $1961 \mathrm{r}$.

${ }_{198}$ Nie mógł być też uznany za instytut naukowo-badawczy w myśl ustawy z 17 lutego

199 Zob. przyp. 175.

200 Tamże. 
którego Zarząd miał być „najwyższą władzą Stowarzyszenia ŻIH i prowadzonego przez to Stowarzyszenie Instytutu w okresie między Walnymi Zebraniami” (par. 24) 201. Zarząd nie mógł - jak stwierdzał Epsztejn - stanowić władzy nad Instytutem, ponieważ nadzór (merytoryczny i finansowy) nad nim sprawowała PAN, a dyrektor Instytutu był „,służbowo i personalnie” niezależny od Zarządu. Ten ostatni, w opinii dyrektora, „posiadał relacje tylko do członków Stowarzyszenia”, nie miał ich natomiast „do pracowników Instytutu”. Warto nadmienić, że kompetencje dyrektora i Rady Naukowej nie były - wbrew poglądowi Ilii Epsztejna - ustalone w Ustawie z dnia 25 lipca 1985 r. o jednostkach badawczo-rozwojowych, ponieważ - jak wynika z przeprowadzonej analizy - jej przepisy nie zostały rozciągnięte na ŻIH. Według opinii Epsztejna Zarząd w stosunku do Instytutu posiadał tylko jedno uprawnienie: „występowanie do PAN z wnioskiem o powołanie i odwołanie dyrektora Instytutu". Ówczesny dyrektor wskazywał także na pozbawioną sensu ingerencję Zarządu w sprawy kadrowe i organizacyjne Instytutu. Podstawą do wyrażenia takiego stanowiska były zgłoszone propozycje uprawnień Zarządu do opiniowania kandydatów na funkcje zastępców dyrektora Instytutu i „kierowników działalności merytorycznej”. Zdaniem Epsztejna opinia Zarządu była zbędna, skoro powołanie osób na kierownicze stanowiska wymagało uzgodnienia z Polską Zjednoczoną Partią Robotniczą i związkami zawodowymi oraz zasięgnięcia opinii Rady Naukowej. W przypadku uzgodnienia kandydatów z pozostałymi partnerami brak pozytywnej opinii Zarządu znacznie komplikowałby tryb powołania osób na wspomniane stanowiska.

Ilia Epsztejn dostrzegał jednak pozytywne rozwiązania w przedłożonym przez Zarząd projekcie. Doceniał m.in. - co w świetle przeprowadzonej analizy nie zdaje się potwierdzone faktami - że projekt „nie identyfikuje »Stowarzyszenia « $\mathrm{z}$ »Instytutem «"202. Z generalnej opinii dyrektora Instytutu na temat projektu opracowanego przez Zarząd wynikało, że zapisy statutu pozbawiały go uprawnień przyznanych w rozporządzeniu z 18 sierpnia 1986 r. (par. 4) ${ }^{203}$. Warto nadmienić, że konflikt z Zarządem, którego kulminację stanowił przyjęty przez ten organ projekt statutu, był przyczyną wypowiedzenia przez Epsztejna stosunku pracy.

${ }^{201}$ ASŻIH. Uwagi Ilii Epsztejna, z 2 lutego 1987 r., do projektu statutu ŻIH.

${ }^{202}$ Tamże.

${ }^{203}$ ASŻIH. Pismo dyrektora Biura Kontroli PAN do Biura Organizacyjno-Prawnego PAN, z 29 czerwca $1987 \mathrm{r}$. 


\section{Status prawny Żydowskiego Instytutu Historycznego w Polskiej Rzeczypospolitej Ludowej}

Jaki był zatem rzeczywisty stan prawny ŻIH? Regulowało go przede wszystkim - o czym wzmiankowano - zarządzenie nr 63 Przewodniczącego Komitetu Nauki i Techniki z 29 października 1969 r. w sprawie wykazu jednostek organizacyjnych, w których mogą być zatrudniani pracownicy naukowo-badawczy ${ }^{204}$. W wykazie w nim zawartym (pozycja nr 213) wymieniony był ŻIH. Znalezienie się Instytutu w powyższej grupie jednostek nie było jednak równoznaczne z naukowo-badawczym statusem placówki. Zarządzenie wydane zostało bowiem na podstawie art. 39 ustawy z 17 lutego 1961 r. ${ }^{205}$ Po zmianie właściwości artykułu - powodującej, że zarządzeniu odpowiadał art. 42 ust. 1 jednolitego tekstu ${ }^{206}$ - zawarta w nim delegacja ustawowa wykazem przedmiotowym obejmowała państwowe, społeczne i spółdzielcze jednostki organizacyjne „nie będące instytutami a prowadzące lub koordynujące prace naukowo-badawcze"207. Żydowski Instytut Historyczny, poprzez objęcie wykazem, był więc uważany za organizację społeczną, tj. stowarzyszenie „nie będące instytutem”, a prowadzące działalność naukowo-badawczą.

Na podstawie przeprowadzonej analizy należy przyjąć, że podstawę prawną funkcjonowania posiadało jedynie Stowarzyszenie ŻIH, natomiast instytut naukowo-badawczy był podmiotem, który prawnie nie istniał. Oznaczało to, że działalność statutowa Stowarzyszenia obejmowała prowadzenie pracy naukowo-badawczej przez tę organizację społeczną. Przy wejściu w życie delegacji zawartej w art. 78 ust. 2 z 25 lipca 1985 r. i rozporządzenia Rady Ministrów z 18 sierpnia 1986 r. Instytut nie mógł być, jak sygnalizowano, nimi objęty.

Brak statutowego wyodrębnienia Instytutu ze struktury prawno-organizacyjnej macierzystego Stowarzyszenia nie znajdował natomiast odzwierciedlenia w strukturze kosztów budżetowych. Dotacja PAN dla ŻIH na 1987 r. przeznaczona była na dwa cele: 1) zrównoważenie budżetu na działalność statutową Stowarzyszenia, 2) na działalność instytutu naukowo-badawczego ${ }^{208}$. Należy jednak zauważyć, co potwierdzało istnienie układu zależności między Stowarzyszeniem i Instytutem, że „cele Stowarzyszenia

\footnotetext{
204 Dz.Urz. KNiT z 1970 r. Nr 1, poz. 2.

205 Dz.U. z 1965 r. Nr 19, poz. 129.

${ }^{206}$ Dz.U. z 1975 r. Nr 7, poz. 41.

207 Zob. przyp. 175.

208 Tamże.
} 
były realizowane przez etatowych pracowników" Instytutu, natomiast aktywność społeczną członków wykorzystywano w „niewystarczającym stopniu”209.

Nawiązując do protokołu kontroli przeprowadzonej w ŻIH od lipca do września 1987 r. przez urzędnika Biura Kontroli PAN, p.o. dyrektora Instytutu Maurycy Horn uznał - zgadzając się z zawartymi w nim uwagami - ,że popełnione przez władze zwierzchnie błędy legislacyjne »mogą zostać naprawione « $[. .$.$] przez uchwalenie przez Walne Zebranie członków Stowa-$ rzyszenia ŻIH nowego statutu, w którym zostanie wyraźnie stwierdzone, że Stowarzyszenie prowadzi instytut naukowo-badawczy" ${ }^{210}$. Warto nadmienić, że w protokole kontrolnym postulowano znacznie dalej idącą korektę „błędów” poprzez „utworzenie instytutu naukowo-badawczego »prowadzonego« przez stowarzyszenie »Żydowski Instytut Historyczny w Polsce «"211.

Normy prawne regulujące funkcjonowanie jednostek naukowo-badawczych oraz uwagi pokontrolne w stosunku do Instytutu niejako wymogły na nim podjęcie prac nad radykalną nowelizacją statutu ŻIH. Jego projekt przesłano 14 października 1987 r. do stosownych organów: Biura Organizacyjno-Prawnego PAN i Wydziału Społeczno-Administracyjnego Urzędu m.st. Warszawy. Jednocześnie Zarząd ŻIH na odbytym w tym samym dniu nadzwyczajnym posiedzeniu wyraził pogląd - odnosząc się do sugestii zawartych w protokole kontrolnym - że „Żydowski Instytut Historyczny jako instytut naukowo-badawczy nie powinien być na nowo utworzony [...], ponieważ [...] istnieje de facto co najmniej od 1 X 1947 r." ${ }^{\prime 212}$

Żydowski Instytut Historyczny pozostawał w tym czasie jednym z towarzystw naukowych (w zakresie nauk społecznych i historycznych) dotowanych przez PAN. Traktowany był więc jako towarzystwo skupiające pracowników naukowych, specjalistów w danej dziedzinie nauki. Zaliczano go (obok m.in. Polskiego Towarzystwa Filologicznego, Polskiego Towarzystwa Historycznego, Polskiego Towarzystwa Religioznawczego, Instytutu Zachodniego) do towarzystw w dziedzinie nauk społecznych pracujących „w stacjach naukowych w terenie oraz w ogólnopolskich sekcjach specjalistycznych istniejących przy zarządach głównych towarzystw”213. Żydowski Instytut

${ }^{209}$ ASŻIH. Protokół z Walnego Zgromadzenia Stowarzyszenia ŻIH, odbytego 29 stycznia $1995 \mathrm{r}$.

${ }^{210}$ Zob. przyp. 172.

${ }^{211}$ Zob. przyp. 175

${ }^{212}$ Zob. przyp. 172.

213 APAN, sygn. II-73 W.667/64. Sprawozdanie Zastępcy Sekretarza Wydziału PAN dla Biura Społecznej Działalności Naukowej PAN, z 6 marca 1986 r., dotyczące działalności Towarzystw Naukowych Wydziału I Nauk Społecznych PAN w latach 1980-1985. 
Historyczny („w części funkcjonujący jako towarzystwo”) i Instytut Zachodni miały pośród tych towarzystw „specjalny charakter”, ponieważ były „ściśle związane z instytutami naukowymi” i „finansowane z odrębnej puli" 214 .

W grudniu 1984 i 1985 r. Stowarzyszenie liczyło odpowiednio 104 i 101 członków ${ }^{215}$. W 1985 r. w Instytucie pracowało 13 naukowców, zajmujących 7,5 etatu ${ }^{216}$. W grudniu $1986 \mathrm{r}$. do Stowarzyszenia należało 105 osób, w kwietniu 1987 r. - 137, a w ostatnim miesiącu tego roku - $146^{217}$. Instytut w tym czasie zatrudniał ogółem 54 pracowników w łącznym wymiarze 40,2 etatów. Grono pracowników naukowo-badawczych stanowiło 13 osób (24\% ogółu zatrudnionych). W roku symbolizującym początek przemian ustrojowych w Polsce (1989) Stowarzyszenie zrzeszało 146 członków²18.

\section{Stowarzyszenie Żydowski Instytut Historyczny w okresie transformacji ustrojowej w Polsce}

Znaczący wpływ na funkcjonowanie ŻIH (zwłaszcza na jego wewnętrzną strukturę i podstawy finansowania) miały przemiany ustrojowe w Polsce dokonujące się na przełomie lat osiemdziesiątych i dziewięćdziesiątych $\mathrm{XX}$ w. Instytut dostosowywał się do nich jednak bardziej ewolucyjnie niż - jak to miało miejsce w wielu innych dziedzinach życia społeczno-gospodarczego - w wyniku radykalnych przeobrażeń. W 1989 r. Zarząd przyjął nowy statut Stowarzyszenia ŻIH, w którym dokonano niewielkich - w kontekście relacji między Stowarzyszeniem i Instytutem - poprawek w stosunku do statutu (i jego „radykalnej nowelizacji”) z 1987 r. Według

${ }^{214}$ Zob. przyp. 177.

215 APAN, sygn. II-73 W.667/64. Sprawozdanie przewodniczącego Zarządu ŻIH, Józefa Barskiego, o działalności Instytutu w 1984 r.; Pismo wiceprzewodniczącego Zarządu ŻIH, Ilii Epsztejna, do Biura Społecznej Działalności Naukowej PAN w sprawie sprawozdania z działalności Instytutu w 1985 r.; Sprawozdania z działalności Towarzystw Naukowych Wydziału I Nauk Społecznych PAN w 1985, 1987 i 1989 r.

${ }^{216}$ APAN, sygn. II-73 W.667/64. Pismo wiceprzewodniczącego Zarządu ŻIH, Ilii Epsztejna, do Biura Społecznej Działalności Naukowej PAN w sprawie sprawozdania z działalności Instytutu w $1985 \mathrm{r}$.

217 APAN, sygn. II-73 W.667/64. Pismo przewodniczącego Zarządu ŻIH, Ilii Epsztejna, do Biura Społecznej Działalności Naukowej PAN, z 30 stycznia 1987 r., w sprawie działalności organizacyjnej Instytutu w 1986 r.; Pismo przewodniczącego Zarządu ŻIH, Szymona Datnera, do Biura Społecznej Działalności Naukowej PAN, z 15 lutego 1988 r., w sprawie działalności organizacyjnej Instytutu w 1987 r.; Sprawozdania z działalności Towarzystw Naukowych Wydziału I Nauk Społecznych PAN w 1985, 1987 i 1989 r.

${ }^{218}$ APAN, sygn. II-73 W.667/64. Sprawozdania z działalności Towarzystw Naukowych Wydziału I Nauk Społecznych PAN w 1985, 1987 i 1989 r. 
jego zapisów Instytut naukowo-badawczy nadal pozostawał integralną częścią prowadzącego go Stowarzyszenia ŻIH. Przyjęcie tego aktu prawnego stanowiło jednak podstawę do wpisania, 10 maja 1989 r., Stowarzyszenia ŻIH do rejestru stowarzyszeńn ${ }^{219}$.

Od 1991 r. Instytut znalazł się w zasięgu finansowania Komitetu Badań Naukowych $(\mathrm{KBN})^{220}$. Zmiana nadzoru (z PAN na KBN) oznaczała uznanie ŻIH - zatrudniającego w listopadzie 1992 r. 74 osoby na 51 etatach jedynie za stowarzyszenie. Komitet zobowiązany był do przekazywania Instytutowi środków pieniężnych na działalność ogólnotechniczną oraz subwencjonowanie konkretnych projektów badawczych i publikacji o charakterze naukowym ${ }^{221}$. Dofinansowywanie ŻIH jak „stowarzyszenia naukowego", nie zaś instytutu PAN przyczyniało się do wzrostu niedoboru środków w budżecie (z zaplanowanych na 1992 r. 5 mld zł KBN przyznał jedynie $500 \mathrm{mln} \mathrm{zl})^{222}$. Sytuacja kryzysowa wydawała się na tyle poważna (otrzymywane kwoty nie wystarczały nawet na pensje dla pracowników), że przewodniczący Stowarzyszenia i dyrektor Instytutu wystosowali list do przewodniczącego KBN. „W obliczu śmiertelnego zagrożenia dalszego bytu [...] placówki” przedstawiciele „Stowarzyszenia Żydowski Instytut Historyczny w Polsce oraz podporządkowanego mu Instytutu” zwrócili się do przewodniczącego KBN z propozycją znalezienia dla Instytutu „formuły umożliwiającej finansowanie jego zasadniczej działalności przez Państwo Polskie" ${ }^{223}$. Stowarzyszenie zasugerowało trzy możliwe warianty: a) finansowanie ŻIH ze środków stanowiących odszkodowanie za utraconą własność przedwojennych gmin żydowskich; b) umieszczenie odpowiednich działów merytorycznych ŻIH w budżetach Ministerstwa Kultury i Ministerstwa Edukacji Narodowej (MEN); c) finansowanie statutowej działalności ŻIH, jako placówki specjalnej, bezpośrednio przez KBN ${ }^{224}$.

Oprócz dramatycznego tonu listu do przewodniczącego KBN (przy braku szybkiej decyzji o zmianie sposobu finansowania jego autorzy przewidywali nawet zamknięcie placówki 1 stycznia 1993 r.) uwagę zwraca

219 ASŻIH. Wyciąg z rejestru stowarzyszeń VIII Wydziału Cywilnego Sądu Wojewódzkiego w Warszawie (7 września 1990 r.).

${ }^{220}$ ASŻIH. Sprawozdanie z działalności ŻIH w latach 1990-1992.

${ }^{221}$ Środki celowe pochodziły również z innych źródeł (m.in. MKiS, Joint). Tamże.

${ }^{222}$ ASŻIH. Protokół nr 3 z zebrania Zarządu Stowarzyszenia ŻIH odbytego 9 września $1992 \mathrm{r}$.

${ }^{223}$ ASŻIH. Pismo przewodniczącego Stowarzyszenia ŻIH, Michała Friedmana, i dyrektora ŻIH, Daniela Grinberga, do Przewodniczącego Komitetu Badań Naukowych, wystosowane 24 listopada $1992 \mathrm{r}$.

${ }^{224}$ Tamże. 
podkreślenie usytuowania Instytutu, o którego dobro zabiegano, w strukturze organizacyjnej Stowarzyszenia. Określenie „podporządkowany” Stowarzyszeniu oznaczało jednoznacznie, że w początkowym okresie przemian ustrojowych w kraju nadzór nad Instytutem wciąż sprawowało Stowarzyszenie, dyktując warunki jego działania.

Ze względu na trudną sytuację finansową, wynikającą w dużym stopniu ze statusu prawnego ŻIH, Zarząd stanął po raz kolejny przed wyzwaniem przeprowadzenia ,zmian statutowych i strukturalnych Instytutu”225. Z propozycją ich dokonania wystąpił przewodniczący KBN. Ustosunkowując się do pisma złożonego mu przez ŻIH, zaproponował nadanie Instytutowi statusu jednostki badawczo-rozwojowej. Przewodniczący zwrócił się ponadto do PAN o rozważenie przejęcia funkcji organu nadzorującego ŻIH. Objęcie nadzorem Akademii wymagało jednak spełnienia następujących warunków:

- zmiany statutu Stowarzyszenia ŻIH polegającej na wyłączeniu z niego działalności naukowo-badawczej przy jednoczesnym pozostawieniu Stowarzyszeniu zakresu działań typowych dla towarzystw naukowych;

- zawarcia porozumienia pomiędzy Sekretarzem Naukowym PAN a Stowarzyszeniem ŻIH o przejęciu przez Akademię spraw związanych z działalnością naukowo-badawczą, będących do tego czasu w gestii Instytutu (m.in. jego majątku i pracowników);

- przyjęcia uchwały przez Prezydium PAN o utworzeniu Instytutu jako placówki Akademii i zaakceptowaniu jej przez Prezesa Rady Ministrów ${ }^{226}$.

W styczniu 1993 r. podjęto dodatkowe konsultacje w celu rozwiązania trudnej sytuacji apelującego o pomoc ŻIH. Oprócz strony bezpośrednio zainteresowanej brali w nich udział przewodniczący KBN oraz Minister Kultury i Sztuki. Głównym tematem spotkań było wyodrębnienie ze struktury Stowarzyszenia Instytutu jako jednostki naukowo-badawczej, której organem założycielskim miało być MKiS ${ }^{227}$.

${ }^{225}$ Zob. przyp. 222.

${ }^{226}$ Pod uwagę brano również przyjęcie rozwiązania, które zastosowano w przypadku wspomnianego Instytutu Śląskiego w Opolu. Prowadziłoby ono do utworzenia Instytutu jako jednostki badawczo-rozwojowej, której organem nadzorującym byłby inny organ administracji państwowej, natomiast PAN sprawowałaby nad nim nadzór naukowy. Zakres tego nadzoru byłby wtedy ustalony na podstawie porozumienia między Akademią a organem nadzorującym. ASŻIH. Notatka wicedyrektora Biura Prezydialnego - Zespołu Prawnego PAN dla wiceprezesa, Sekretarza Naukowego PAN, z 7 stycznia 1993 r.

227 ASŻIH. Pismo prezesa Stowarzyszenia ŻIH, Michała Friedmana, i dyrektora ŻIH, Daniela Grinberga, do Ministra Kultury i Sztuki, z 25 maja 1993 r. 


\section{Odrębność i zależność: Stowarzyszenie i Instytut Naukowo-Badawczy}

Na Walnym Zebraniu, które odbyło się 18 maja 1993 r., członkowie Stowarzyszenia, dostrzegając konieczność rezygnacji z prowadzenia własnego Instytutu, uchwalili statut Stowarzyszenia ŻIH, wyłączając z niego część dotycząca jednostki naukowo-badawczej. Na tym samym posiedzeniu zebrani upoważnili Zarząd do bezpłatnego użyczenia majątku Stowarzyszenia ŻIH na rzecz nowo powstającego ,instytutu naukowo-badawczego Żydowski Instytut Historyczny"228.

W dalszej kolejności Stowarzyszenie zwróciło się do MKiS z prośbą „o powołanie instytutu naukowo-badawczego pod nazwą Żydowski Instytut Historyczny, który kontynuowałby działalność istniejącego do tej pory Instytutu stanowiącego organiczną część Stowarzyszenia"222. Ministerstwo wyraziło wprawdzie wolę powołania takiej jednostki, lecz na przeszkodzie stanęły trudności natury finansowej. Resort nie był bowiem w stanie znaleźć dodatkowych funduszy i zaproponował współfinansowanie (przy wykorzystaniu dotychczasowych środków budżetowych) z KBN ${ }^{230}$.

W okresie postępujących przekształceń, na podstawie art. 65 wielokrotnie już przywoływanej ustawy z 25 lipca 1985 r. ${ }^{231}$, w związku z par. 1 Zarządzenia Nr 13 MKiS z 18 kwietnia 1994 r. w sprawie utworzenia jednostki badawczo-rozwojowej pod nazwą „Żydowski Instytut Historyczny - Instytut Naukowo-Badawczy", stanowisko kierownika (dyrektora) Instytutu objął (25 maja 1994 r.) Daniel Grinberger2.

Stowarzyszenie wciąż szukało odpowiedniej formuły współpracy z Instytutem. Nieuregulowany status prawny placówki naukowo-badawczej (do czerwca 1994 r. posiadała jedynie, niezatwierdzony przez Radę Naukową, regulamin) utrudniał realizację zadań zapisanych w statucie Stowarzyszenia. W połowie $1994 \mathrm{r}$. Stowarzyszenie postawiło na wspólne działania z Instytutem głównie na dwóch polach: edukacyjnym i popularyzatorskim. Zabiegało również o podpisanie z nim umowy o współpracy. Jednym

${ }^{228}$ ASŻIH. Protokół z Walnego Zebrania członków Stowarzyszenia ŻIH odbytego 18 maja $1993 \mathrm{r}$.

${ }^{229}$ Zob. przyp. 227.

${ }^{230}$ ASŻIH. Protokół z zebrania Zarządu Stowarzyszenia ŻIH odbytego 19 stycznia $1994 \mathrm{r}$.

${ }^{231}$ Dz.U. z 1991 r. Nr 44, poz. 194 z późniejszymi zmianami.

${ }^{232}$ ASŻIH. Pismo Ministra Kultury i Sztuki, Kazimierza Dejmka, do prof. Daniela Grinberga, wystosowane 25 maja $1994 \mathrm{r}$. 
z przedsięwzięć objętych zakresem wspólnych działań planowano uczynić budowę Muzeum Historii Żydów Polskich. W celu umocnienia swojej podmiotowości Stowarzyszenie postulowało, aby w przyszłym statucie, przyjętym już po formalnym wyodrębnieniu się Instytutu, umieścić zapis, że „kontynuuje tradycje Instytutu Nauk Judaistycznych”. W opinii Zarządu rozstrzygnięcia wymagały kwestie jednobrzmiącej nazwy obu instytucji oraz dóbr Stowarzyszenia, które powinny być oddane Instytutowi w użytkowanie, nie zaś w depozyt ${ }^{233}$.

W wyniku decyzji zainteresowanych organów państwowych (oprócz wymienionych resortów także m.in. Ministerstwa Finansów) oraz ustanowienia nowych aktów prawnych Instytut nabył osobowość prawną 30 września 1994 r. Rolę organu założycielskiego Instytutu Naukowo-Badawczego wzięło na siebie Ministerstwo Kultury i Sztuki; inne instytucje odmówiły. Formalne procedury związane z wyodrębnieniem się Instytutu Naukowo-Badawczego trwały jednak do połowy $1995 \mathrm{r}$.

Pierwsze porozumienie między Stowarzyszeniem Żydowski Instytut Historyczny a Żydowskim Instytutem Historycznym - Instytutem Naukowo-Badawczym (ŻIH - IN-B), określające zasady współdziałania obu instytucji, podpisano 7 listopada 1994 r. Będące punktem wyjścia do zawarcia umowy szczegółowej regulującej poszczególne sfery współpracy zawierało ono zapis, że „Instytut powstał z inicjatywy Stowarzyszenia; został powołany do działalności naukowo-badawczej prowadzonej przy wykorzystaniu zbiorów Stowarzyszenia i w tym znaczeniu istnienie i działalność Instytutu N-B jest nierozerwalnie związana ze Stowarzyszeniem" $(\text { par. } 3)^{234}$.

Stowarzyszenie, by mieć gwarancję podpisywania dalszych umów, pozostawało - na mocy porozumienia (par. 2) - właścicielem budynku przy ul. Tłomackie 3/5, jego wyposażenia i zbiorów (archiwalnych, bibliotecznych i muzealnych) $)^{235}$. Warto wspomnieć, że odzyskiwanie budynku, przyznanego w 1969 r. PAN, było procesem żmudnym i skomplikowanym. Zgodnie z prawem bowiem ŻIH nie był właścicielem budynku, lecz

${ }^{233}$ ASŻIH. Protokół z zebrania Zarządu Stowarzyszenia ŻIH odbytego 10 czerwca $1994 \mathrm{r}$.

${ }^{234}$ ASŻIH. Porozumienie zawarte 7 listopada 1994 r. między Stowarzyszeniem ŻIH, reprezentowanym przez przewodniczącego, Michała Friedmana, a Żydowskim Instytutem Historycznym - Instytutem Naukowo-Badawczym, reprezentowanym przez dyrektora, Daniela Grinberga.

${ }^{235}$ Tamże. Zob. także ASŻIH. Protokół z Walnego Zgromadzenia Stowarzyszenia ŻIH w Polsce, odbytego 29 stycznia 1995 r. Przemówienie przewodniczącego Stowarzyszenia ŻIH, Michała Friedmana. 
jednostką administrującą obiekt stanowiący własność państwa. Stowarzyszenie proponowało, aby przedmioty nabyte przez Instytut od daty utworzenia pozostały jego własnością, natomiast w przypadku zbiorów opowiadało się za ciągłością, co oznaczało, że wszystkie nowo pozyskane eksponaty miały należeć do Stowarzyszenia. Jego przewodniczący postulował, żeby mimo odrębności prawnej obu instytucji stworzyć ,jedną całość zmierzającą do wspólnego celu, posługując się jednak środkami zróżnicowanymi, swoistymi dla ich sytuacji prawnej i funkcji społecznych"236. Organy opracowujące statuty Stowarzyszenia i Instytutu starały się, aby $\mathrm{z}$ jednej strony były one komplementarne, $\mathrm{z}$ drugiej zaś uwzględniały specyfikę obu instytucji.

W dniu 26 maja 1995 r. podpisano w formie aktu notarialnego umowę regulującą kwestię praw Stowarzyszenia do nieruchomości przy ul. Tłomackie $3 / 5^{237}$. Dobiegły również końca formalności związane $\mathrm{z}$ wyodrębnieniem Instytutu, polegające na uregulowaniu spraw jego siedziby oraz odpowiedzialności za zbiory ${ }^{238}$. Zgodnie z umową zawartą pomiędzy obiema instytucjami 23 maja $1995 \mathrm{r}^{239}$ ich siedzibą pozostał budynek przy ul. Tłomackie 3/5. Stowarzyszenie było prawnym właścicielem gruntu i budynku oraz zbiorów obejmujących Archiwum i przedmioty muzealne, a także Biblioteki zawierającej m.in. cenne starodruki. Na mocy umowy Stowarzyszenie udostępniło Instytutowi na czas nieokreślony nieodpłatne korzystanie zarówno z budynku, w którym mieściły się siedziby obu instytucji, jak i wszystkich zbiorów (zgodnie z ich przeznaczeniem), z obowiązkiem pokrywania kosztów eksploatacji i pod warunkiem należytej dbałości o budynek i zbiory. Uzgodniono również, że wydatki i nakłady przekraczające zakres bieżącej eksploatacji i konserwacji będą pokrywane ze środków Stowarzyszenia ${ }^{240}$. W uzupełnieniu do sprawozdania z działalności Zarządu Stowarzyszenia ŻIH w latach 1989-1995 jego przewodniczący, Michał Friedman, stwierdził:

Formalny rozdział Stowarzyszenia i Instytutu wniósł nowe zasady współpracy, których musimy się wzajemnie uczyć. Zgodnie z tradycjami i naszym statutem jesteśmy

${ }^{236}$ ASŻIH. Protokół z Walnego Zgromadzenia Stowarzyszenia ŻIH, odbytego 29 stycznia 1995 r. Przemówienie przewodniczącego Stowarzyszenia ŻIH, Michała Friedmana.

${ }^{237}$ ASŻIH. Sprawozdanie z Walnego Zgromadzenia Stowarzyszenia ŻIH odbytego 4 czerwca 1995 r.

${ }^{238}$ Bardziej precyzyjnych uzgodnień wymagał jeszcze podział niektórych zadań i kompetencji (np. rozliczania wydawnictw).

${ }^{239}$ ASŻIH. Sprawozdanie Komisji Rewizyjnej Stowarzyszenia ŻIH z 4 czerwca 1995 r.

${ }^{240}$ Tamże. 
właścicielami zbiorów i budynku, które udostępniamy Instytutowi dla realizacji ich oraz naszych celów statutowych. [...] wielu pracowników Instytutu jest członkami naszego Stowarzyszenia. Nakłada to na obie instytucje wzajemne zobowiązania oraz wyznacza zakresy współpracy ${ }^{241}$.

Stowarzyszenie wzięło na siebie zadania opiniowania kandydatów na stanowisko dyrektora, określania tematyki i kierunku badań naukowych oraz przygotowywania programu prac Instytutu. W zakres swoich kompetencji wpisało ponadto możliwość udzielania pracownikom Instytutu zleceń, za których wykonanie otrzymywaliby oni wynagrodzenie, mogące być jednym ze sposobów dofinansowania placówki naukowo-badawczejej ${ }^{242}$.

Po formalnym wyodrębnieniu się Instytutu zatwierdzono na Walnym Zgromadzeniu 4 czerwca 1995 r. nową wersję statutu Stowarzyszenia, zrzeszającego 212 członków i dysponującego 2,5 etatami $^{243}$. Według statutu - już po zmianach wpisanych do rejestru stowarzyszeń 28 lutego $1996 \mathrm{r}^{244}$ - głównym celem Stowarzyszenia Żydowski Instytut Historyczny było „zachowanie i utrwalenie pamięci o historii i kulturze Żydów polskich oraz ich wkładzie w kulturę światową" (par. 7) ${ }^{245}$. Zgodnie ze zgłaszanymi wcześniej aspiracjami podkreślano, że nawiązuje ono „do tradycji Towarzystwa Krzewienia Nauk Judaistycznych oraz Głównej Biblioteki Judaistycznej” (par. 2), a także szerzy „wiedzę o dorobku [...] JIWO w Wilnie i Centralnej Żydowskiej Komisji Historycznej”. Kultywując i popularyzując tradycję Żydów polskich, wspierając badania naukowe w zakresie historii i kultury żydowskiej oraz prowadząc działalność edukacyjną, Stowarzyszenie stawiało na „ścisłe współdziałanie z Żydowskim Instytutem Historycznym - Instytutem Naukowo-Badawczym [...], polegające w szczególności na wszechstronnym wspieraniu Instytutu [...] oraz wymianie informacji i doświadczeń" (par. 8). W statucie podkreślono, że Stowarzyszenie realizuje swoje cele poprzez „udostępnienie Instytutowi N-B zbiorów muzealnych, bibliotecznych i archiwalnych, miejsca na siedzibę w pomieszczeniach budynku przy Tłomackie 3/5 w Warszawie” (par. 8). Potwierdzono również wsparcie dla działalności „Muzeum Historii

${ }^{241}$ Zob. przyp. 237.

${ }^{242}$ Fundusze Stowarzyszenia tworzone były przez składki członkowskie oraz dotacje otrzymywane od instytucji krajowych i zagranicznych na konkretne programy.

${ }^{243}$ ASŻIH. Uzupełnienie do sprawozdania z działalności Zarządu Stowarzyszenia ŻIH w latach 1989-1995, wygłoszonego na Walnym Zgromadzeniu 4 czerwca 1995 r.; Sprawozdanie Komisji Rewizyjnej Stowarzyszenia ŻIH z 4 czerwca 1995 r.

${ }^{244}$ ASŻIH. Postanowienie Sądu Wojewódzkiego w Warszawie, z 28 lutego 1996 r., o wpisaniu do rejestru stowarzyszeń zmian statutu.

${ }^{245}$ ASŻIH. Statut Stowarzyszenia Żydowski Instytut Historyczny. 
Żydów Polskich, którego Stowarzyszenie jest inicjatorem i współzałożycielem” (par. 8). Zapis, że „Stowarzyszenie opiera swą działalność na pracy społecznej członków", nie pozostawiał wątpliwości co do jego charakteru ${ }^{246}$.

W zakres swoich kompetencji Stowarzyszenie wpisało - zacieśniając w ten sposób i tak bliski układ relacji z Instytutem - „Opiniowanie projektów planów Instytutu N-B”, „Uczestnictwo Przewodniczącego lub upoważnionych przez niego członków Zarządu w pracach Rady Naukowej Instytutu N-B”, „Opiniowanie kandydatur na stanowisko dyrektora Instytutu N-B” (par. 30) 247. W posiedzeniach Zarządu Stowarzyszenia zagwarantowano natomiast uczestnictwo dyrektorowi Instytutu lub jego zastępcy oraz przedstawicielowi Rady Naukowej lub jego zastępcy.

\section{Podsumowanie}

Na podstawie analizy zgromadzonego materiału źródłowego ustalono, że powstanie Żydowskiego Instytutu Historycznego nie jest równoznaczne $\mathrm{z}$ formalnym rozpoczęciem działalności przez Stowarzyszenie Żydowski Instytut Historyczny. Geneza tej pierwszej instytucji wiąże się bezpośrednio z ukonstytuowaną w 1944 r. Centralną Żydowską Komisją Historyczną, która po trzech latach funkcjonowania - najpierw w Lublinie, a następnie w Łodzi - uległa przekształceniu w ŻIH, z siedzibą w Warszawie. Zarówno Instytut, jak i wcześniej Komisja działały w strukturze organizacyjnej Centralnego Komitetu Żydów w Polsce, który był największą i w dużym stopniu autonomiczną organizacją Żydów polskich, dążącą do reprezentowania ich w charakterze monopolisty w stosunkach z rządem polskim i tzw. zagranicą. Likwidacja CKŻP w 1950 r., która nastąpiła w wyniku demontażu żydowskiej autonomii narodowo-kulturalnej, pozbawiła ŻIH instytucjonalnego wsparcia. W celu znalezienia dla niego nowej formy i podstawy regulacji prawnej rozpoczęło jeszcze w tym samym roku działalność Stowarzyszenie o takiej samej nazwie. Ramy prawno-organizacyjne istnienia Instytutu Stowarzyszenie ŻIH ustanowiło w 1951 r., legalizując swój statut. W gronie założycieli Stowarzyszenia znaleźli się pracownicy, a zarazem współzałożyciele Instytutu z jego dyrektorem Bernardem Markiem na czele. Obie jednostki organizacyjne, choć różniące się genezą, wpisały się w jeden ciąg przekształceń instytucjonalnych obejmujących działalność naukowo-badawczą zapoczątkowaną powstaniem CŻKH.

246 Tamże.

247 Tamże. 
Cele, jakich realizacji na mocy statutu podjęło się Stowarzyszenie (prowadzenie „całokształtu badań w zakresie historii Żydów”, „samodzielnych prac naukowo-badawczych”, „opracowanie i redagowanie publikacji naukowych"), odpowiadały kompetencjom placówki naukowo-badawczej. Stworzenie ram prawno-organizacyjnych funkcjonowania Instytutu w połączeniu z zadaniami, jakie wzięło na siebie Stowarzyszenie, i środkami do ich realizacji ustanowiło ścisły związek między Stowarzyszeniem i Instytutem. Te fundamentalne początki silnego układu zależności warunkowały dalszą drogę rozwoju obu instytucji. „Żydowski Instytut Historyczny jest stowarzyszeniem zarejestrowanym i posiada osobność prawną”, a jego „Członkowie zobowiązani są do [...] pracy społecznej na rzecz Żydowskiego Instytutu Historycznego", głosił statut z 1964 r. Ze struktury Stowarzyszenia ŻIH nie wyodrębniało instytutu naukowo-badawczego również żadne z postanowień statutu z 1976 r. Niewielki krok w stronę podkreślenia jego odrębności organizacyjnej poczyniono w 1987 r., opracowując - szeroko dyskutowany - projekt nowego statutu. Stwierdzał on m.in., że „Organem ŻIH powołanym do realizacji głównych celów Stowarzyszenia jest wchodzący w jego skład instytut naukowo-badawczy". Zapis ten nie pozostawiał jednak wątpliwości co do tego, że Instytut stanowił część macierzystego Stowarzyszenia, które konsekwentnie zresztą było bytem tożsamym z Żydowskim Instytutem Historycznym. W statucie stwierdzono bowiem, że „ŻIH jest stowarzyszeniem zarejestrowanym i posiada osobowość prawną".

Wszystkie statuty przyjmowane przez Stowarzyszenie ŻIH (w 1964, 1976 i 1987 r.) utrwalały podporządkowanie Instytutu Zarządowi Stowarzyszenia, prowadząc do wytworzenia się organicznej więzi między nimi.

Zasadnicza zmiana w tym względzie nastąpiła w okresie transformacji ustrojowej w Polsce. Zarówno na początku lat pięćdziesiątych, jak i czterdzieści lat później szukano właściwej formy i podstawy regulacji prawnej dla funkcjonowania, a w zasadzie finansowania ŻIH. Jego bardzo trudna sytuacja ekonomiczna, wynikająca w dużym stopniu ze statusu prawnego, wymusiła na Zarządzie Stowarzyszenia przeprowadzenie ,zmian statutowych i strukturalnych Instytutu”. Stowarzyszenie wystąiło do MKiS z prośbą „o powołanie instytutu naukowo-badawczego pod nazwą Żydowski Instytut Historyczny, który kontynuowałby działalność istniejącego do tej pory Instytutu stanowiącego organiczną część Stowarzyszenia”. Instytut Naukowo-Badawczy nabył osobowość prawną 30 września 1994 r., a rola organu założycielskiego przypadła MKiS. 
Formalności związane z wyodrębnieniem Instytutu, polegające na uregulowaniu spraw jego siedziby oraz odpowiedzialności za zbiory, dobiegły końca 23 maja 1995 r., kiedy podpisano umowę pomiędzy nim a Stowarzyszeniem ŻIH. W myśl tego aktu prawnego siedziby obu instytucji mieściły się w budynku przy ul. Tłomackie 3/5. Stowarzyszenie było prawnym właścicielem gruntu i budynku oraz zbiorów (archiwum, przedmiotów muzealnych i biblioteki). Nieodpłatnie na czas nieokreślony udostępniło Instytutowi Naukowo-Badawczemu korzystanie zarówno z budynku, jak i wszystkich zbiorów.

Po formalnym wyodrębnieniu się Instytutu Stowarzyszenie na Walnym Zgromadzeniu 4 czerwca 1995 r. uchwaliło nową wersję statutu. W myśl jego postanowień - zatwierdzonych po zmianach w $1996 \mathrm{r}$. i stanowiących podstawę kolejnych statutów - Stowarzyszenie podjęło się ścisłego współdziałania z ŻIH - IN-B, polegającego na wszechstronnym wspieraniu Instytutu.

Konkludując, należy stwierdzić, że wraz z wyodrębnieniem Instytutu N-B ze struktury prawno-organizacyjnej Stowarzyszenia ŻIH nie doszło do zerwania układu silnej zależności między obiema instytucjami. Poprzez wszechstronne, a będące zarazem realizacją celów Stowarzyszenia, wsparcie udzielane Instytutowi utrzymał się znaczący wpływ Stowarzyszenia ŻIH na działalność Instytutu N-B. Na zasadach analogicznych do tych, które ustalono w 1995 r. w wyniku wzajemnej umowy i statutu Stowarzyszenia ŻIH, obie instytucje weszły w XXI wiek.

Andrzej Rykała

Uniwersytet Łódzki aaronbund@gazeta.pl andrzej.rykala@geo.uni.lodz.pl 